University of Louisville

ThinkIR: The University of Louisville's Institutional Repository

Electronic Theses and Dissertations

$5-2017$

\title{
Media framing and public opinion of refugees: news coverage of Hungarian refugees, 1956-57.
}

Cecelia M. Hunt

University of Louisville

Follow this and additional works at: https://ir.library.louisville.edu/etd

Part of the International and Intercultural Communication Commons, Journalism Studies Commons, and the Mass Communication Commons

\section{Recommended Citation}

Hunt, Cecelia M., "Media framing and public opinion of refugees: news coverage of Hungarian refugees, 1956-57." (2017). Electronic Theses and Dissertations. Paper 2639.

https://doi.org/10.18297/etd/2639

This Master's Thesis is brought to you for free and open access by ThinkIR: The University of Louisville's Institutional Repository. It has been accepted for inclusion in Electronic Theses and Dissertations by an authorized administrator of ThinkIR: The University of Louisville's Institutional Repository. This title appears here courtesy of the author, who has retained all other copyrights. For more information, please contact thinkir@louisville.edu. 
MEDIA FRAMING AND PUBLIC OPINION OF REFUGEES:

NEWS COVERAGE OF HUNGARIAN REFUGEES, 1956-57

By

Cecelia M. Hunt

B.A., Indiana University Southeast, 2012

\begin{abstract}
A Thesis
Submitted to the Faculty of the

College of Arts and Sciences of the University of Louisville In Partial Fulfillment of the Requirements
\end{abstract}

For the Degree of

\author{
Master of Arts \\ in Communication \\ Department of Communication \\ University of Louisville \\ Louisville, Kentucky
}

May 2017 
Copyright 2017 by Cecelia M. Hunt

All rights reserved 

MEDIA FRAMING AND ACCEPTANCE OF REFUGEES:

NEWS COVERAGE OF HUNGARIAN REFUGEES, 1956-57

By

Cecelia M. Hunt

B.A., Indiana University Southeast, 2012

A Thesis Approved on

May 11, 2017

by the following Thesis Committee:

John P. Ferré

Greg B. Leichty

Ann Elizabeth Willey 


\section{ACKNOWLEDGEMENTS}

I would like to thank my main advisor and mentor, Dr. John Ferré, for his helpful edits, feedback, and patience. I would also like to thank the other members of my committee, Dr. Greg Leichty and Dr. Beth Willey, for their comments and helpful suggestions.

Finally, I would like to thank my fellow graduate students, Abi John, Olivia Eurek, and Caitlyn Crenshaw, who encouraged me to keep working and researching when I thought I would never finish. 


\section{ABSTRACT \\ MEDIA FRAMING AND PUBLIC OPINION OF REFUGEES: \\ NEWS COVERAGE OF HUNGARIAN REFUGEES, 1956-57 \\ Cecelia M. Hunt}

May 11, 2017

This thesis examines how United States news media framed Hungarian refugees of the 1956 Hungarian Revolution. It begins with a historical overview of the revolution and an explanation of how the media have framed other refugee groups and influenced American public opinion by doing so. Then the thesis explains how 713 news articles, coded for attributes and value frames, described Hungarian refugees from November 1956 until December 1957. American news media framed Hungarian refugees in a positive way, which matched the positive American public opinion of this particular refugee group.

The thesis is divided into five chapters. Chapter one introduces the topic, theories, and method used throughout the rest of the thesis. Chapter two examines how Associated Press and United Press wire services described Hungarian refugees. Chapter three examines how three weekly news magazines, US News and World Report, Time, and Newsweek described Hungarian refugees. Chapter four examines how the New York Times described Hungarian refugees. Chapter five provides an overview of the findings, strengths and limitations of the thesis, and directions for future research. 


\section{TABLE OF CONTENTS}

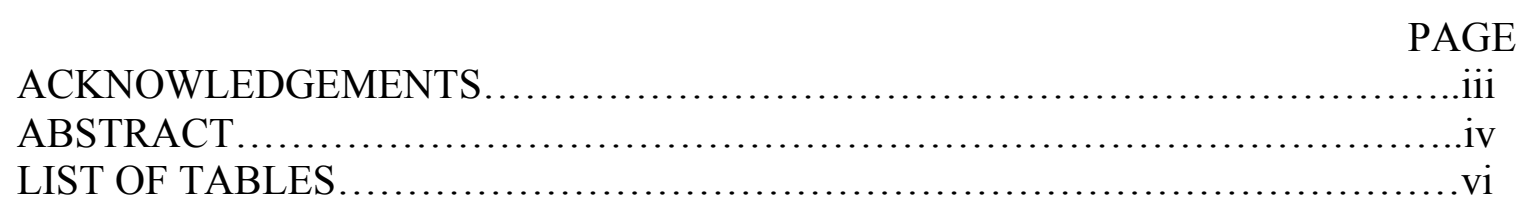

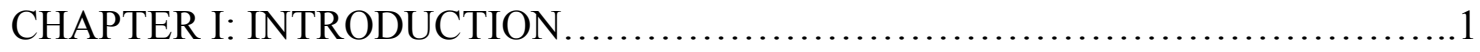

CHAPTER II: ASSOCIATED PRESS AND UNITED PRESS COVERAGE.........17

CHAPTER III: US NEWS AND WORLD REPORT, TIME, AND NEWSWEEK

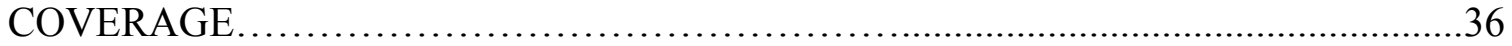

CHAPTER IV: NEW YORK TIMES COVERAGE................................48

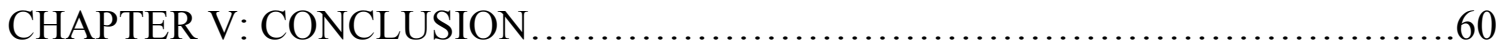

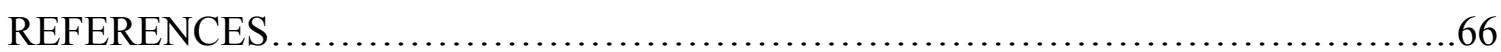

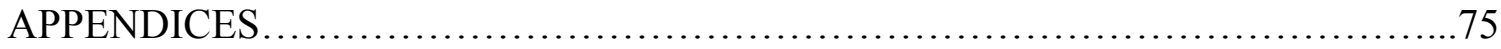

CURRICULUM VITA........................................................ 93 


\section{LIST OF TABLES}

PAGE

\section{TABLE}

2.1. Frequency of Top 20\% Associated Press Attributes......................... 19

2.2. Frequency of Top 20\% United Press Attributes...........................20

2.3. Value Frames of Hungarian Refugees................................... 31

2.4. Frequency of Top Five Values Used by The Associated Press...................31

2.5. Frequency of Top Five Values Used by The United Press....................32

3.1. Frequency of Top 20\% US News and World Report Attributes...................38

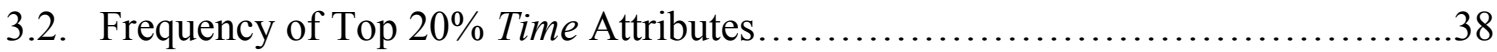

3.3. Frequency of Top $20 \%$ Newsweek Attributes.............................. 39

3.4. Frequency of Top Five Values Used by US News and World Report...............44

3.5 Frequency of Top Five Values Used by Time Magazine........................44

3.6. Frequency of Top Five Values Used by Newsweek..........................44

4.1. Frequency of Top 20\% of New York Times Attributes.........................49

4.2. Frequency of Top Five New York Times Values............................57 


\section{CHAPTER I}

\section{INTRODUCTION}

The Soviet Union invaded Hungary in 1944 and turned it into a Soviet satellite state, controlling the way Hungarians worked and lived. Under communist control, Hungarian citizens were expected to voice support for the government, and those who spoke out against communism paid dearly, usually by torture or deportation (Weinstock, 1970). Tensions became so high that some Hungarians turned in their own family members for making anti-communist remarks (Teglas, 1998). Hungarians who supported communism or wanted to put their family in good standing with the government joined the Államvédelmi Hatóság (ÁVH), a Hungarian secret police organization that served as an extension of the Soviet police (Mevius, 2005). The goal of the communist leaders may have been to eliminate class distinctions, but people who supported communism received better jobs and enjoyed more freedom than those who did not.

Some Hungarians risked their safety and freedom and spoke out against the communist government. For examples, students organized democratic student unions to oppose the government and its restrictions. In October 1956, students in Budapest demonstrated against Soviet control of their country (Teglas, 1998). The demonstration was peaceful until Soviet soldiers attacked the protestors, who fought to defend themselves. This confrontation was the beginning of the Hungarian Revolution. 
Fighting between revolutionaries and Soviet soldiers escalated. The number of protestors grew, and the Hungarians fighting to end communism held their own against the Soviets. At first, the revolutionaries believed that capitalist countries, including the United States, would help Hungary defeat the Soviet army. But the governments of the countries that considered helping Hungary ultimately chose not to. Many representatives to the United Nations were focused on the Suez Canal crisis and did not believe that the revolution in Hungary would happen for many more months (Granville \& Garthoff, 2004). When the uprising occurred, United Nations military resources had already been dedicated to the Middle East. The United States, in particular, also feared the consequences of antagonizing the Soviet Union (Bon Tempo, 2008). For a short period of time, Hungarians believed that the Soviet armed forces were beginning to leave the country permanently because the rebels were continuing to gain control in Budapest, but after 12 days of violent protests, a replenished Red Army returned for vengeance (Sebestyen, 2006).

When the Hungarians realized that they would receive no outside help, they knew that the people who participated in the uprising were in danger. Soviet forces renewed their grip on Hungary, then began to round up rebels and put them on trial with the likely sentence of imprisonment or death (Teglas, 1998). For that reason, many Hungarians who fought in the revolution fled with their families. Many escaped with just the clothes they were wearing and a few possessions (Sebestyen, 2006). The refugees went primarily to Austria because they were unsure if they would be welcomed in communist Yugoslavia, but in January 1957, Yugoslavia also began sheltering Hungarians who sought asylum. In total, 200,000 Hungarians left their homeland after the revolution ("White 
House Statement: Total Put at 200,000," 1957). Once Hungarians began to flee their country and reports began spreading about the oppression Hungarians experienced, governments of other countries started supporting the refugees by sending funds to Austrian and Yugoslav camps and by increasing emergency immigration quotas so the refugees could leave the camps and resettle. Although 200,000 refugees initially escaped to Austria and Yugoslavia, 180,000 resettled in other European countries and the United States (UNHCR, 2006).

In the United States, President Eisenhower offered unprecedented support for the Hungarian refugees, including funding and supplies for Hungarians in refugee camps and those accepted to the United States. He also urged Congress to increase immigrant quotas and asked Americans to help however they could. The President's support for the Hungarians was a consolation for not sending American military forces to Hungary to fight with the Hungarian revolutionaries against the Soviets (Bon Tempo, 2008). Having stayed out of the conflict in Hungary, the United States was able to support Hungarian refugees as they left the country without further aggravating America's strained relationship with the Soviet Union. Out of the 200,000 Hungarians who fled, more than 30,000 came to America from November 1956 to May 1957 under the Refugee Relief Act, and another 5,000 found their way to the United States by the end of 1957 (Desilver, 2015; Coriden, 1996). Compared to other countries that took in the fleeing Hungarians, the United States accepted the most refugees who left Austria and Yugoslavia due to overcrowding (Nemes, 1999). 


\section{The Hungarian Revolution in the News}

Like today’s wars and conflicts, footage of the 1956 Hungarian Revolution was shown around the world. One of the few remaining video collections from the time is a 14-minute compilation of seven Universal International News newsreels that were shown in American movie theaters ("The 1956 Hungarian Revolution as Depicted in Newsreels," 2007). In all of the newsreels, Universal's Ed Herlihy reported on scenes of violence, oppression, and escape from communist Hungary.

The first reel shows scenes from Hungary during the revolution and reports that blood and plasma were being sent to Hungary from the United States. Herlihy says, "The human need is clear." Reel two describes the "passion for liberty" in the "beautiful city of Budapest scarred by conflict" and ends by stating, "Hungary's newfound freedom is menaced before the martyrs of revolution go to their rest." The third reel tells of political demonstrations in Italy and around the world on behalf of Hungarians. Reel four depicts Hungary's "hour of hope and heartbreak," the time between the initial revolution and Soviet forces return to reconquer the country.

Next Herlihy says, "The flames of liberty and revenge against tyranny leap high," and, "[The Hungarians] are showing the world that freedom is worth fighting for" as they "turned the tables on their Soviet tormentors." He follows by describing the return of the Soviet forces as "5000 [tanks] come with 200,000 Soviet troops to snuff out the torch that brave Budapest had held so high." Before the scene ends he reports, "From their heart

and from their flag, the Hungarian people have ripped Russia's hated symbol," explaining that Hungarians throughout the country literally cut the Soviet symbol from the center of Hungarian flags. Reel five, which calls the Hungarians "heroic freedom fighters," 
describes Hungarian refugees escaping their country by traveling for days on foot in freezing temperatures, braving swift rivers, and narrowly avoiding Russian machine gun fire.

Shifting to the United States Herlihy says, "Yesterday's suffering is eased by the hope of tomorrow." He reports, "The refugees have found the freedom for which their countrymen have fought and died." In the final reel Herlihy describes the "enfolding arms of America" that welcomed Hungarians to the United States (archive.org, 2007). Herlihy's intimate and elaborate reports and accounts from other journalists provided Americans with a picture of Hungarian refugees fleeing their country after fighting against the communist Soviets. Certainly, the specific way both broadcast and print media described the events in Hungary would have influenced the opinions and knowledge that Americans developed about Hungarians as they fought in the revolution, and later, when they came to the United States as refugees.

\section{Public Opinion of Refugees}

The refugee crisis that unfolded in 1956 was hardly the first or last of its kind. As an established, democratic country, the United States has long been a place of refuge for foreigners escaping wars, religious persecution, environmental crises, and other dangers. When such events break out, waves of people attempt to come to the United States, some to start a new life and others to wait in safety until the situation in their home country improves. Although the number has fluctuated throughout history, in 2015 Congress approved a request from President Obama's administration to increase the United States refugee quota from 70,000 to 85,000 in 2016 amid humanitarian crises in the Middle East 
(United States Department of State, Department of Homeland Security, and Department of Health and Human Services, 2015; Igielnik \& Krogstad, 2017). Between 1948 and 2015, approximately 4.5 million refugees were granted admission into the United States (Federation for American Immigration Reform, 2008; United States Department of State, 2015). Many Americans welcome such refugees and even assist them with finding jobs and housing. Others, however, view refugees as outsiders who take jobs, deplete public treasuries, and commit crimes.

Public opinion about an entire refugee group can affect how individual refugees are received when they arrive in the United States. Whether refugees are welcomed or spurned, when they arrive in a new country their initial experiences can affect the rest of their time in that country. For this reason, it is important to understand how public opinion of each refugee group is created. Public opinion about refugees is shaped by several factors, including prejudice, the employment rate, and similarities or differences between host country citizens and each refugee group's culture, majority religion, and ethnicity (Shamir \& Shamir, 2000). Because the media help shape public opinion, researchers have studied the link between negative news coverage of refugees or immigrants and the challenges that they face in host countries. When the media skew an issue in a xenophobic or welcoming direction, the government officials that the slant favors gain the power to make and change laws, a process that applies to the Holocaust as well as 2015 Syrian refugee crisis (Entman, 2007).

Ending over a decade before the Hungarian Revolution, another crisis that sparked international attention from the media was the Holocaust. Although over 200,000 Jewish refugees settled in the United States between 1933 and 1945, they were not 
always welcomed by American citizens or the government (United States Holocaust Memorial Museum, 2017). At the beginning of the Holocaust, visa policies for refugees were restricted in the United States due to the State Department assertions that Nazi spies could enter the country by claiming to be refugees. The rules were so strict that in 1939 , the SS. St. Louis, a ship carrying over 900 Jewish refugees, was denied entry in Havana and then again in Miami by the State Department and President Roosevelt because the United States had already reached its refugee quota for the year (United States Holocaust Memorial Museum, 2017). Although journalists reported on the matter sympathetically, none suggested that the refugees should be allowed to disembark in the United States (United States Holocaust Memorial Museum, 2017). Mirroring the attitude established by the media, an earlier 1938 poll found that Americans felt bad for the Jews in Nazi Germany, but $67 \%$ believed that political refugees should be kept out of the United States due to the conditions the country was already facing, and $18 \%$ felt that refugees should be allowed in based on existing immigration quotas, but that the quotas should not be increased to accommodate additional refugees (Gallup \& Robinson, 1938). As a result, the S.S. St. Louis returned to Europe. Although some of the refugees were able to escape to the United Kingdom, more than 250 of the S.S. St. Louis's passengers did not survive the Holocaust (Ogilvie \& Miller, 2006).

A more recent crisis began in 2011, when Syrians were forced to flee their homeland to escape civil war sparked by various violent parties including Muslim extremists. Again public opinion of refugees caused difficulties as the Syrians tried to settle into safer countries. In Germany, refugees reported 1,031 attacks on their homes in 2015 and 800 attacks by October 2016 . These attacks ranged from property damage to 
arson. There were also 11 attempted murders of refugees in the first 10 months of 2016 (“800 Crimes Against Refugee Homes Reported This Year,” 2016). In the United States, an increase in Islamophobia or the "unfounded hostility towards Islam... [resulting in] unfair discrimination against Muslim individuals and communities, and ... the exclusion of Muslims from mainstream political and social affairs" (Conway, 1997, p. 4) affects not just refugees, but even life-long American citizens, who account for approximately $37 \%$ of Muslims in America (Pew Research Center, 2011). In 2015, hate crimes against Muslims increased 67\% from the year before ("Latest hate crime statistics released," 2016).

While Syrian refugees were fleeing the violence and oppression in their homeland, the media focused on terrorist attacks committed by Muslim extremists in Syria instead of the plight of Syrian citizens. Americans began associating Syrians with terrorists because of their Muslim religion, and several conservative governors in the United States tried to keep Syrian refugees out of their states (Fantz \& Brumfield, 2015). The news slanted against Muslims because they practice the same religion as the Middle Eastern terrorists, and leading conservative state governors could make these statements and decisions with little resistance from citizens. Corresponding with the slant of the news, a 2015 Gallup found that only $37 \%$ of Americans supported the plan to allow 10,000 Syrian refugees into America (Jones, 2015). Further research about how the media frame specific political and social crises could increase our understanding of the factors that affect refugees' opportunities to assimilate, get jobs, make friends, and even avoid persecution. 


\section{Framing Research}

Recognized as the first person to study frame analysis, Goffman (1974) explored how people comprehend specific topics based on the way information about the topic is communicated to them. Researchers eventually began narrowing their study of media framing to examine its effect on public opinion. To understand how frames in the media work, one must first recognize a basic premise of social cognition. In framing, the media focus on specific parts of a subject of communication, which increases the salience of that specific part of the communication act for the receiver or audience (Fiske \& Taylor, 1991). When reporting a story, the media must first choose which stories to share - gatekeeping - then decide how much attention each story will receive - agenda setting (Kuypers, 1997). According to McCombs, Shaw, and Weaver (1997), media framing is an extension of agenda setting: beyond simply providing consumers with topics to think about, media guide the ways that consumers form their opinions and judgments.

Many studies suggest that media framing of crises and other social problems affects not only how the public perceives and reacts to an event, but also how the public forms attitudes and judgments (De Vreese, 2005; Brinson \& Stohl, 2012). For example, in Framing Muslims, a book about the way news reports spread and sustain stereotypes about Muslims, Morey and Yaqin (2011) found that uses of negative Muslim stereotypes by the media increased after the September 11 terror attacks. Morey and Yaqin suggested that the negative framing led to protests against Muslims, such as Pastor Terry Jones' 2010 plan to burn copies of the Quran publicly. In addition, Morey and Yaqin posited that the media's framing of Muslims as the "other" also caused a greater divide between Muslims and non-Muslims in general. In a book about how the media frame domestic 
abuse and other social problems, Berns (2004) explained that news and entertainment media consistently "frame domestic violence as a problem about the victim" and therefore "fail to expose the role of the abuser and society" by focusing on the actions or inactions of the victim (p. 176). Berns suggested that the way the media frame victims does not allow the public to understand domestic violence fully, and therefore inhibits prevention. Riles et al. (2015) conducted an experiment to determine how framing of cancer patients by online news outlets affected readers' opinions about the patients. The authors found that while cancer or message type did not affect the way readers thought about a cancer patient, inclusion of information about whether or not the patient could have prevented his or her cancer significantly influenced how audiences thought about the patient.

In a study on the effects of competing frames on public opinion, Chong and Druckman (2007) acknowledge that audiences constantly deal with messages from opposing opinion leaders that are meant to sway public opinion. De Vreese (2005) also specifies that the consequences of frames happen at both individual and societal levels. Immediate effects occur when individuals' attitudes or beliefs are changed or reinforced based on the way news is framed. Over time, though, the effects on individuals can develop into societal effects, which can affect major processes including "political socialization, decision-making, and collective actions" (p. 52). At both individual and societal levels, then, framing can also affect public opinion of refugees.

\section{Media Framing and Public Opinion of Hungarian Refugees}

In 1956 and 1957, the main way that people outside of Hungary received 
information about the revolution was through news media. Because Hungarians were restricted on what they were able to say about their communist rulers, news agencies outside of Hungary relied primarily on reports coming from refugees. Therefore, Americans were learning about the refugees primarily from stories told by news media, and the way they framed the stories inevitably influenced public opinion about Hungarian refugees.

Shortly after the Hungarian Revolution in October 1956, a Gallup poll reported that $50 \%$ of Americans would be willing to house a Hungarian refugee (Gallup, 1972). The approval rate was high compared with polls that asked similar questions about other refugee groups. For example, a 1939 Gallup poll found that only $27 \%$ of Americans supported the government's plan to ask Americans to house refugee children from Germany (Gallup, 1972). A CBS News/New York Times poll in 1994 found that only $15 \%$ of Americans approved of letting Cuban refugees enter the United States (CBS News, 1994).

The positive public opinion about Hungarian refugees coming to the United States meant that Americans would support Hungarian refugees in various ways. Churches and other organizations around the country helped Hungarians find homes and jobs. Private companies voluntarily went to Camp Kilmer, the processing center for the Hungarian refugees, to interview people for jobs as they arrived (“Job Help for Refugees," 1956). Some universities waived fees and long admission processes for college students. Overall, Hungarian refugees were welcomed and encouraged to consider America their new home. 
It is important to distinguish refugees from immigrants. People in both categories may face similar situations when moving to a new country, but the United Nations High Commissioner for Refugees (1951) defined a refugee as:

any person who, owing to well-founded fear of persecution for reasons of race, religion, nationality, membership of a particular social group or political opinion, is outside the country of his nationality and is unable or, owing to such fear, is unwilling to avail himself of the protection of that country; or who, not having a nationality and being outside the country of his former habitual residence as a result of such events, is unable or, owing to such fear, is unwilling to return to it. (p. 6)

On the other hand, an immigrant is a foreign-born individual who is legally or illegally residing in a country. This distinction will be important in the analysis section once it is determined whether the media framed Hungarians primarily as refugees or as immigrants because refugees are typically seen as victims in need of support, while immigrants typically receive less sympathy in the country to which they choose to relocate (Conner, 2016).

\section{Method}

When frame analysis initially became popular, it encountered an abundance of criticism because of its disparate uses across disciplines. In an article aimed at clarifying the use of frame analysis specifically in the communication field, Entman (1993) defined frame analysis as "a way to describe the power of a communication text." He went on the explain, "Analysis of frames illuminates the precise way in which influence over a human 
consciousness is exerted by the transfer (or communication) of information from one location - such as a speech, utterance, news report, or novel - to that consciousness" (p. $51)$.

This thesis uses frame analysis to determine how news reports in the United States from November 1956 to December 1957 portrayed Hungarian refugees. This time frame was chosen because the Hungarian Revolution started at the end of October 1956, so by the beginning of November, Hungarian refugees were fleeing to Austria and Yugoslavia. December 1957 was the last officially active month of the United States Refugee Relief Act, which was put in place as an emergency action so that the United States could accept Hungarian refugees over the standard yearly quota. This research identified the attributes and values found within the most popular American news outlets of the time period. Attributes were defined as nouns, adjectives, and verbs that described who the refugees were, what they were doing, and what was happening to them. Values were defined as broader, overarching messages that journalists reported. The goal of the research was to answer the following questions:

RQ1: What attributes and values were included in American news reports about Hungarian refugees in from October 1956 to December $1957 ?$

RQ2: If the attributes and values used by the media were overwhelmingly positive or negative, do they match the public opinion of Hungarian refugees?

Three frame analyses were conducted on popular 1950s news outlets: daily AP and UP wire service reports, three weekly magazines, and the prestige newspaper, The New York Times. Using these three types of sources provided a triangulation of data and ensured that the study included the main sources that people were getting their news from 
during and after the Hungarian Revolution. According to Flick (2004), "triangulation of data combines data drawn from different sources and at different times in different places or from different people," and serves to increase the validity (p. 178).

Each article was inspected for attributes and values given to Hungarians either directly or indirectly. An inductive approach was used to identify the attributes in the articles. As the articles were examined, every new attribute was added to the codebook. Values previously used in framing research by Price and Tewksbury (1997) and Valkenburg et al. (1999) were adapted and expanded upon to fit the articles about Hungarian refugees. For example, Price and Tewksbury studied personalization economic frames in their research and Valkenburg et al. studied frames of conflict and responsibility. Their frames were adapted for this thesis and became frames of character, economic impact, support, and responsibility, for which all of the articles were coded. Attributes and values were listed as they were found and organized by similarities and frequency.

Based on frequency, this thesis discusses the top $20 \%$ of attributes and top five values used by each news outlet. The top $20 \%$ of attributes were chosen for discussion because they were the attributes that readers encountered most often. With the exception of AP and New York Times articles, the attributes outside of the top 20\% were used 8 times or less, so readers may not have noticed them. The top five values were chosen for discussion because there is a rapid decline in frequency after the fifth value in almost every news outlet. For example, in the New York Times the fifth value is used 21 times, but the sixth value is used only seven times.

Although $96 \%$ of American households had radios 55\% of American households 
had televisions by 1954 , the majority of Americans still preferred to get their news from newspapers (Emery, Emery \& Roberts, 2000; Baughman, 1993). Broadcast news was prevalent during the 1950 s, but this study focused on print media because of the scarcity of radio and television news broadcasts available from the time period. Regarding radio, most of what is housed in libraries and archives around the country is in collections from specific journalists or reporters whose scripts have been donated. An indexed compilation of news radio broadcasts from entire networks, such as NBC, CBS, and MBS, does not exist. In 2013, the Library of Congress commissioned a task force to examine this problem. The task force recognized that a number of issues have prevented or destroyed past efforts to preserve historic radio recordings, including improper storage, natural disasters, and various copyright laws applied to historical recordings (loc.gov, 2013). Similar problems affect historic television: Television news archives are incomplete, and existing archives include few television broadcasts about Hungarian refugees. For example, the archive of NBC has only one clip with sound and three without sound. Television collections that are complete and indexed by network do not go back to 1956. For example, holdings of Vanderbilt Television New Archive date back only to 1968 .

\section{Sample}

Articles were included for analysis if they included the terms "Hungarian(s)" and "refugee(s)" or "immigrant(s)" in the title or body, and were published in 1956 or 1957. In total, 713 articles were included in the sample: 407 from wire services, 106 from news magazines, and 200 from the New York Times. Prior to being sorted and categorized by 
similarity and frequency, $300 \mathrm{AP}$ articles contained 1759 attributes and 435 value frames, and 107 UP articles had 561 attributes and 157 values. Thirty-one US News and World Report articles contained 327 attributes and 38 value frames, 40 Time articles contained 180 attributes and 79 value frames, and 35 Newsweek articles contained 260 attributes and 76 value frames. Two hundred New York Times articles contained 1245 attributes and ten value frames used 339 times.

\section{Findings}

This study found that news media consistently reported on Hungarian refugees in a positive and sympathetic tone. The wires services, news magazines, and the New York Times used similar attributes and values to described refugees primarily as oppressed victims of communism who were similar to Americans. Regardless of the news outlets' article lengths and style of writing, they all published stories about the refugees' abilities to assimilate and work hard in the United States after struggling to flee dangerous oppression. These descriptions coincide with the positive public opinion that the majority of Americans had of the Hungarian refugees. 


\section{CHAPTER II}

\section{ASSOCIATED PRESS AND UNITED PRESS COVERAGE}

In the 1950s, most American adults read daily newspapers (Mickelson, 1957). Dailies around the country ran articles from Associated Press (AP) and United Press (UP) wire services in order to share the latest national and international news with readers. Begun in 1848, AP was the oldest and largest wire service in the United States by the 1950s (Erwin, 1953). By 1956, AP had already shown its commitment to reporting from behind the Iron Curtain, even if it meant danger for the journalists. For example, in 1951 William N. Oatis, AP journalist and chief of bureau for the wire service in Czechoslovakia, was arrested, accused of being a spy for the United States, and he was jailed until 1953 (Oatis,1953). Aware of the dangers, the service continued to publish extensively about the Cold War. By 1960, AP served approximately 3,500 United States news agencies.

UP was AP's primary competitor, and even though UP trailed AP in circulation numbers, it still reported thoroughly on the Hungarian Revolution, in part due to having an active bureau chief, Henry Shapiro, in the Soviet Union during the 1950s (Emery, Emery \& Roberts, 2000). Shapiro and other reporters in the U.S.S.R. were able to provide the UP wire service with reports of the revolution and its aftermath. UP reached its peak circulation in the 1950s, prior to being sold to the Hearst Corporation in 1958 (Krebs, 1982). When the Hearst corporation bought UP in 1958, the wire service merged 
with the International News Service and competed with AP until the 1980s (Emery, Emery \& Roberts, 2000).

This chapter examines the presence and frequency of attributes and values found in AP and UP articles published in the United States. Three regional newspapers were chosen for this purpose: Louisville, Kentucky's The Courier-Journal (Southeast), Cedar Rapids, Iowa's Cedar Rapids Gazette (Midwest), and Eugene, Oregon's Eugene Register Guard (West). Taken together, wire service articles from these newspapers provide a comprehensive look at what many Americans read about Hungarian refugees from November 1956 to December 1957.

The large number of short AP and UP articles provided readers with a broad array of stories to attract a broad array of readers. This chapter will show that AP and UP attribute frames fall into four distinct categories: refugees as typical people, victims in need of help, refugees in America, and refugees who escaped. Each article also used at least one broader value frame, which exposed readers to information about the support being given to refugees, the economic impact of refugees, and the positive character of individual refugees.

\section{Attributes}

After being sorted and organized by frequency, the AP articles yielded 133 unique attributes used a total of 2012 times and the UP articles yielded 103 unique attributes used a total of 613 times. This chapter discusses the $20 \%$ most frequently used attributes. (For a complete table of attributes, see Appendix A). Tables 2.1 and 2.2 illustrate the similarity between AP and UP articles. There are more articles from AP, and some 
attributes fell within the top $20 \%$ in the AP table that were not included in the smaller $20 \%$ UP table. Both wire services covered the same stories and used similar attributes to describe the Hungarian refugees. AP and UP provided newspaper readers with a cohesive and consistent view of the refugees.

Because the wire services used similar methods to describe Hungarian refugees, the rest of this chapter combines the attributes they used. This method is fitting because each newspaper examined used both AP and UP wire service articles, so readers would have read articles from both services.

Table 2.1

Frequency of Top 20\% Associated Press Attributes

\begin{tabular}{ll}
\hline Attribute & Frequency \\
\hline Received Help and Supplies & 134 \\
Youth & 128 \\
Relational & 122 \\
Struggle to get into Austria & 112 \\
Jobs & 86 \\
Ages & 85 \\
Supported by a Government Official & 67 \\
Fled & 66 \\
Assimilating/Learned English & 62 \\
Arrived by Ship or Air to the US & 54 \\
Victims of Soviet Oppression & 50 \\
Adult/Men/Women & 46 \\
Number to Austria & 46 \\
Accepted to the US (General) & 45 \\
Problem/Need & 45 \\
Welcomed & 42 \\
Accepted to Other Countries & 41 \\
Procedures/Processes & 41 \\
Student & 36 \\
Feared for Family Still in Hungary & 33 \\
Shot by Soviets/Hungarian police & 32 \\
Found/Sought Freedom/Safety/Haven & 31 \\
Escapees & 27 \\
Positive Emotion (Cheerful, Excited, &
\end{tabular}


Hopeful, Joyful, Merry, No Weeping

and Wailing, Smiling) 26

Participated in the Revolution 24

Unhappy with their circumstances $\quad 22$

Conditions in Hungary (negative) 21

Table 2.2

Frequency of Top 20\% United Press Attributes

\begin{tabular}{ll}
\hline Attribute & Frequency \\
\hline Received Help and Supplies & 50 \\
Relational & 44 \\
Jobs & 35 \\
Youth & 34 \\
Supported by a Government Official & 21 \\
Problem/Need & 20 \\
Adult/Men/Women & 19 \\
Struggle to get into Austria & 19 \\
Ages & 17 \\
Assimilating/Learned English & 17 \\
Fled & 15 \\
Procedures/Processes & 13 \\
Welcomed & 13 \\
Arrived by Ship or Air to the US & 11 \\
Accepted to the US (General) & 10 \\
Found/Sought Freedom/Safety/Haven & 10 \\
Number to Austria & 10 \\
Positive Emotion (Cheerful, Happy, & \\
Hopeful, Joyful, Laughing, Optimistic) & 10 \\
Shot by Soviets/Hungarian police & 10 \\
Conditions in Hungary (negative) & 9
\end{tabular}

\section{Refugees as typical people}

AP and UP articles described the Hungarian refugees in a way that evoked images of real people as readers learned about the crisis in Hungary and the need for help. Americans could relate to this articles. The wire services often provided specific ages or age ranges of the refugees, in addition to nouns such as "child," "youth," "boy," "girl," 
"adult," "man," and "woman." Although articles frequently included these attributes, more stories described young refugees than adults, even though the majority of Hungarian refugees were middle aged men (Coriden, 1996). This emphasis gave readers an image of children who needed help.

For example, one article reported at length on a teenager confined to a wheelchair who participated in the revolution by handing out flyers. When the Soviets returned and the boy's parents found out he was in danger of being imprisoned or deported, they packed up a few of their belongings and escaped Hungary with the boy and his sister. They pushed the teenager in his wheelchair for miles "through woods and across ditches" to reach safety in Austria. The United States accepted the family as refugees, and the article described the boy's father carrying him down the stairs of the airplane ("What Price Freedom," 1956, p. 2). It was clear that young refugees like this boy were in the care of family members. The families of young people who participated in the revolution were often willing to pack up with short notice and leave their lives behind in order to make sure their sons and daughters were safe. In fact, AP and UP articles used the attribute "orphan" only one time during the time frame studied to describe Hungarian refugees.

AP and UP commonly used relational terms to described the refugees within family structures. Whether reading about families being reunited after reaching safety or families who escaped Hungary together, readers often learned about refugees in terms of their place within family units. The descriptions in AP articles included "mother," "father," "brother," and "sister," but did not describe family members outside of immediate family. In addition, UP described a refugee as a "grandmother" once. Other 
attributes in this category describe refugees becoming family during the same time that they sought refuge, by using words and phrases like "couple," "fiancé," "gave birth," or "got married."

In addition to describing the refugees in terms of their age and identity, the news wires explained that the majority of Hungarian refugees had education and employment prior to escaping Hungary. Because young people started the Hungarian Revolution, it is not surprising that AP articles commonly used the word "student" to describe refugees. Most of the articles that described refugee students mentioned the steps that they took to get back into school after resettlement. Others who participated in the revolution wanted to go to the United States because the communist government had barred them from attending universities in Hungary. For example, one young man explained that he wanted to study to become a veterinarian, but the communist government in Hungary would not allow it because his father was a lawyer, and the government punished his family for not being working class ("Hungarians Thirst for US Schools," 1956, p.12).

The wire services often used employment status to describe adult refugees. This category includes jobs that the Hungarians had prior to escaping as well as jobs that they received once they left Hungary. Almost all of the articles that describe jobs the refugees received once they left Hungary refer to those who came to the United States. Not only did employment information about refugees paint a better picture of who they were, but it also served as a way to demonstrate the hard working, skilled, and smart qualities of the refugees, qualities that Americans respected. 


\section{Refugees in need of help}

Of course, if the articles reported only surface-level information, the Hungarian refugees would not have received such strong sympathy from Americans and others around the world. For example, heart-wrenching stories about refugees loaded into trailers to be deported to Soviet work camps by the Soviets were not only sad to read, but they also allowed readers to draw comparisons between the treatment of Hungarians and the treatment of Jews being forced into cattle carts and taken to concentration camps during the Holocaust. These stories and others that described the negative and oppressive conditions in Hungary created a "need" frame of the refugees, which reinforced sympathy and desire to help the refugees.

The call for help did not end once Hungarians decided to leave their conflicted homeland. Many articles focused on the refugees' attempts to flee Hungary. AP articles also often pointed out that the refugees were victims of a force that was out of their control. These descriptions mentioned that the escapees or victims fled from communism, the Iron Curtain, and Soviet oppression. The failed revolution was also commonly mentioned in the same context. Some wire service reports made it clear that refugees began to realize how much they had lost at the same time that they finally reached freedom. For example, one article described a woman who had been accepted to France but was "crying bitterly" as the ship she was on departed. She was safe but unhappy because reaching safety meant she had to leave her home ("Safe but Not Happy," 1956, p.2).

Articles often described the struggle to get into Austria, where the majority of refugees went as they escaped Hungary on foot. Stories described Hungarians wading 
through icy creeks and canals or walking through freezing marshes because the peak time of escape was during the winter of 1956-57. In November 1956, Soviet soldiers blew up a bridge in the border town of Andau, which the refugees frequently used as a way to avoid crossing in the water, so multiple articles described the way refugees used limbs and sticks to create a makeshift bridge or balance above the cold water ("Austrian Police Kill Russian Inside Border,” 1956, p.1).

In addition to articles about the dangerous geography that the refugees had to cross in order to get to safety, readers also learned that many refugees did not make it to freedom because Soviet soldiers and Hungarian police shot them down near the AustrianHungarian border. The stories about shootings emphasized the danger of attempting escape to Austria. One article reported that a man and his 22-year-old daughter were caught by Hungarian police near the border. The police demanded all of their belongings, and when the daughter refused the orders, the police fatally shot her and ordered the man to leave his daughter's body and run across the border by himself ("Reds Reportedly Rob, Kill Hungarian Refugee,” 1957, p. 17). Often even those who made it to Austria had to be treated for bullet wounds. Stories described the lengths that the desperate Hungarians went to in order to get out of Hungary, which may have strengthened the idea of the kind of danger that the Hungarians appeared to be in if they did not receive help from the outside world.

AP and UP routinely updated the number of refugees arriving or already in Austria. Sometimes the information was used as a preface to other stories about the refugees, but many times the reports alluded to a problem, which continued the "need" frame. Some stories were more direct by discussing the "refugee problem" or "refugee 
crisis" in terms of overcrowding and the need for help from other countries. Some articles implored readers to help the refugees arriving to the United States by describing how little they had and what they needed. Others listed relief agencies to which readers could donate money or supplies if they wanted to help.

Finally, many reports described refugees by using the roles they played in the revolution prior to escaping Hungary. Descriptions ranged from refugees who admitted to killing Soviet soldiers and Hungarian secret police to the children and teenagers who handed out flyers to keep the public informed when Hungarian radio broadcasts could no longer be trusted. AP articles celebrated refugees who participated in the revolution, including those who admitted to torturing or murdering communists, by heralding their bravery and defiance, which may have swayed readers to think of the Hungarians as their fellow countrymen, together in the fight against communism.

\section{Refugees in America}

As soon as it was clear that the flow of refugees arriving in Austria was not going to slow down for quite a while, AP and UP began publishing articles that reported what other countries did to care for the refugees. For the most part, acceptance to countries other than the United States was straightforward. Governments offered generous immigration quotas and halted or reduced health and security screenings. Multiple articles mentioned the Canadian government's promise to accept any and all Hungarian refugees who wished to come to the country. There was no quota, and officials did not check the refugees' qualifications until they arrived in Canada, if ever. Not long after the magnitude of the Hungarian refugee problem became clear, other countries began to 
criticize the United States for not doing enough to alleviate the strain put on Austria by the refugees or to increase quotas for the acceptance of more refugees to the United States so they would be out of harm's way.

Throughout 1957, articles described the ways that the United States accepted Hungarians. Sometimes the articles specified that the refugees were accepted permanently and received a visa, or they explained that the refugees were accepted only on a temporary basis as "parolees." The parolees were refugees who would be allowed to request a visa in the future at Congress's discretion but were not granted one when they first arrived to the United States. Most of the time, however, AP and UP did not specify how the United States accepted the refugees. Articles about the general acceptance of Hungarian refugees to the United States gave less information about the specific nature of their arrival, and readers would not have known if the refugees were coming to the United States permanently or as parolees.

Not only did articles describe what the United States was doing to get refugees to safety, but they also told readers how government officials helped the Hungarians. The newspapers included AP and UP stories about President Eisenhower repeatedly requesting to raise the refugee quota the United States. The wire services also published assurances from Vice President Nixon that the refugees coming to the United States were hardworking anti-communists. Articles described support that refugees received from former President Herbert Hoover, Attorney General Rogers, and Francis Walter.

Interestingly, Walter, the Chairman of the House Immigration Subcommittee, was also co-author of The Immigration and Nationality Act of 1952, which placed strict regulations on immigration policies in the United States. Walter began challenging his 
own Act after he visited the Austrian-Hungarian border and witnessed Soviet soldiers shooting down a potential refugee attempting get to safety in Austria. However, before the end of 1957, a few articles reported that Walter wanted the United States to halt acceptance of Hungarians after rumors surfaced of communists infiltrating the refugee groups headed to the United States.

Although the refugees could not avoid suspicion altogether, the majority of Americans still welcomed them. This positive reaction may have a great deal to do with the fact that many articles told readers what was going on behind the scenes to admit the best refugees to the United States. For example, one article explained that in order for refugees to come to the United States, they must have sponsors to ensure that they will not need government assistance. They also experienced "a full medical examination that includes a lung x-ray," to confirm that the refugees were not afflicted with tuberculosis (“300 Refugee Arrivals Due to US Daily,” 1956). From other articles, readers learned that in order to come to the United States, refugees had to answer questions about any participation with the Communist party in Hungary. The refugees also had to have skills that would make them employable or relatives or sponsors willing to take care of them and help them get settled. The articles about procedures and policies would have put readers' minds at ease that the refugees did not threaten national security or the economy.

AP and UP articles often told of the lengths that people went to in order to make refugees feel welcome. Articles told of parties thrown to honor newcomers and last minute weddings provided for those who had fallen in love shortly before or just after escaping Hungary. Other articles described citizens or government officials excitedly awaiting the arrival of ships or airplanes carrying refugees. Some told of American 
relatives who were ready to accept their family members to the United States and help them get accustomed to their new lives. Articles about refugees struggling to get to Austria also discussed relief agency representatives or average townspeople waiting in the field for the refugees in the middle of the night to take them to a safe location. By reading these articles, other Americans may have felt more inclined to welcome the refugees to the United States.

In addition to articles that described how welcome refugees were, many discussed the help that refugees received. Articles described refugees receiving clothing, food, and gifts. The news also highlighted information about housing, jobs, and scholarships (for university students). The articles informed readers specifically when religious groups, such as individual churches and larger organizations like the Church World Service, helped the refugees.

\section{Refugees who escaped}

Many articles described the lives of Hungarian refugees who made it to safety. These stories gave readers a sense of how refugees resettled and adjusted to their new lives. Some also described problems that still existed. In the former, readers who approved of the help that the refugees received would have been pleased to read of their progress. The same readers would have also learned that much still needed to be done to help the refugees.

Other articles provided updates about how the refugees assimilated into life in a new country. In-depth articles described how the refugees liked their new jobs, and others described refugees taking classes to learn English. Only six articles discussed difficulties 
that refugees had with assimilation, most focusing on language barriers that existed immediately after arriving to their new homeland.

AP and UP described happy emotions that refugees experienced when they arrived at refugee camps in Austria or Yugoslavia and when they reached a country that was willing to take them in. These refugees were described as "cheerful," "excited," "hopeful," "joyful," and "not weeping." From these descriptions, readers got a sense that these refugees were different; they did not intend to come to the United States or any other country and live an easier life without working hard. They were in good spirits and were willing to adjust to their new surroundings no matter what it took.

However, not all refugees were happy with their circumstances once they left Hungary. Many of these articles reported on refugees still living in camps. Some had to wait longer than expected to get out of the camps and start the resettlement process. Others were upset about the physical condition of camps in Austria, where they initially had to sleep on straw in drafty old buildings. Finally, when the United States began to slow down its acceptance of Hungarian refugees in April 1957 as the refugee quota was fulfilled, articles reported about refugees who were upset that they could not go to the United States. But according to the reports, few refugees were upset once they left the camps and resettled in a new country. On the contrary, AP and UP often described the refugees as thankful and grateful to those who had helped them. AP articles that described refugees as unhappy may have actually spurred Americans' acceptance of the refugees once they read about the conditions of the camps and the difficulty refugees had getting to the United States.

According to the wire services, once the refugees found freedom, it was often not 
their own happiness that they worried about, but the safety of the family members they left behind in Hungary. Reporters from the wire services interviewed many refugees who did not want to give their names for fear of punishment that could be inflicted on their family by the communists in Hungary. Others wondered what had become of family members who could not be contacted or located but were rumored to have been forced into trains headed to Siberian labor camps. Multiple articles described this fear and gave readers a convincing look at the threat faced both by the refugees who left Hungary and by rebels who decided not to leave.

Overall, AP and UP gave American readers important information and stirred sympathy. The most frequent attributes described the refugees in a positive and likeable manner. A few articles described some refugees as communists and described refugees who misbehaved once they escaped Hungary. However, articles describing refugees as victims fleeing a terrible environment significantly overshadowed these negative stories. The wire services described refugees as people who would fit in well in America, based on their positive attitudes in the face of hardship and their willingness to work hard for a new, safe life.

\section{Values}

In addition to using specific attributes about Hungarian refugees to create frames, overarching values found in the same articles create broader frames. As described in chapter one, twelve values were adapted from previous framing research by Valkenburg et al. (1999) and Price and Tewksbury (1997). The value frames in this study are found in table 2.3. 
Table 2.3

Value Frames of Hungarian Refugees

\begin{tabular}{ll}
\hline Category & Message \\
\hline Support for refugees & Refugees are victim patriots \\
& Refugees are less important than national security \\
& Refugees need help \\
Refugees are good people & Refugees are bad people \\
Character of Refugees & Refugees are just people \\
& Funding refugees has positive consequences \\
Economic impact of refugees & Funding refugees is bad for the economy \\
& Transparency about funding refugees is important \\
& The United States needs to do its share to help \\
Responsibility for refugees & European countries should be helping refugees \\
& Everyone should be helping refugees \\
\hline
\end{tabular}

The most frequent of these value frames, when combined, explained why refugees should be helped, how they were going to help the United States economy as a consequence, and how they would fit in well in the United States. AP articles used 12 values frames 435 times; UP articles used 11 value frames 157 times. As with the attributes, AP and UP articles used the same five values much more frequently than the other seven, so only the top five will be discussed in this section. Tables 2.4 and 2.5 list the top five values and their frequencies. (For a complete list of value frequencies, see

\section{Appendix B.)}

Table 2.4

Frequency of Top Five Values Used by the Associated Press

Value Frequency

Economic impact of refugees - Transparency about funding refugees is important 90 Character of refugees - Refugees are good people

Support for refugees - Refugees are victim patriots 
Table 2.5

Frequency of Top Five Values Used by the United Press

Value

Frequency

Support for refugees - Refugees are victim patriots

Support for refugees - Refugees need help

29

Economic impact of refugees - Transparency about funding refugees is important 27

Character of refugees - Refugees are good people

Economic impact of refugees - Funding refugees has positive consequences

The wire services frequently used the "Support for refugees - Refugees are victim patriots" value frame. The articles that used this value frame informed readers about the conflict in Hungary. Although this frame did not explicitly argue that the refugees should be helped, it did describe Hungarian refugees as patriots fighting against communism, a form of government that Americans hated and even feared, and as victims of Soviet oppression who faced imprisonment, deportation, or death. For example, one AP article discussed a Hungarian government effort to stop refugees from escaping to Austria or Yugoslavia, stating, "A police detachment removed 180 persons, referred to by the Communists as 'defector candidates,' from single train” ("Hungary Closes Gaps to Refugees," 1957, p. 12). Articles that used the "Support for refugees - Refugees are victim patriots" value frame were so dramatic, reporting staggering numbers of Hungarians being affected by the revolution and its aftermath, that American readers likely felt sympathy towards the refugees because they were anti-communist, like the majority of Americans.

Other articles that discussed the conflict in Hungary asserted that the refugees needed or deserved to be helped. For example, one AP article stated, "If you are one of 
the thousands who has wished he could help the Hungarian freedom-fighters in some small way, the way to do it is to send your contribution to your local Red Cross office" (“Help the Hungarians," 1956, p. 2). Other articles that fell into the "Support for refugees - Refugees need help" value frame category addressed the need for other countries to save refugees due to their innocence, positive spirit, or anti-communist ways, which were all qualities that would have made them more likeable to American readers.

Because many articles told of refugees receiving help, it makes sense the wire services also used economic value frames to addressed how funding refugees would affect the economy. Some, such as the articles categorized within the "Economic impact of refugees - Transparency about funding refugees is important" value frame, were similar to the "Support for refugees - Refugees are victim patriots" frame because they focused on providing information to readers, but still did from the perspective that funding refugees was necessarily because of what they had experienced.

Most AP and UP articles coded with this value frame discussed the number of refugees reaching various countries. For example, 15 articles referred to the 21,500 refugees who were going to be admitted to the United States. The articles did not discuss the effects that admitting 21,500 Hungarians would have on the United States. But because the AP and UP articles were so informative about what was being done for the refugees, readers were likely satisfied with how the government was helping the refugees.

However, some articles did focus on the effects that refugees would have on the economies of countries that helped or funded them. The "Economic impact of refugees Funding refugees has positive consequences" value frame appeared 21 times in UP articles and a staggering 59 times in AP articles. Most of the articles that discussed the 
positive effects that helping Hungarians would have on the economy included quotations from government officials. One article highlighting the positive effect that refugees would have on the economy even included a quotation from AFL-CIO Labor Union president George Meany. The AP article reported, "The labor chief said the average Hungarian escaping from Communist oppression is between 25 and 40 years old, in 'his most productive period"” ("Higher refugee quota urged," 1956, p. 14). The testimonies from government officials and employers that established the ways that helping refugees would help the economy would have appealed to readers. Linking refugees with accepting government officials could have made the readers comfortable enough to welcome refugees without worrying that doing so would cause them to lose their own jobs or pay higher taxes, a common fear for citizens when refugees are admitted to the United States.

The final value frame that showed up frequently in AP and UP articles was "Character of the refugees - Refugees are good people." The "character" category was used for articles that discussed specific refugees instead of discussing them as an entire group. Although a few articles described specific refugees who committed crimes in the United States including owning a still and getting into a bar fight, most reports in the "character" category described Hungarian refugees as good, hard working, happy people. For example, one UP article described how a refugee family had worked quickly to assimilate and obtain jobs once they arrived to the United States. The father worked two jobs and even the children in the family had found employment ("Hungarian Refugees Make Good in a Hurry," 1957). This story and others like it showed readers that the refugees embodied traditional American values, including the desire to work hard and 
provide for their own family. American readers would have been able to relate to these values and identify with the refugees. 


\section{CHAPTER III}

\section{US NEWS AND WORLD REPORT, TIME, AND NEWSWEEK COVERAGE}

In the 1950s millions of Americans read the national weekly magazines Time, Newsweek, and US News and World Report. In 1955, Time's circulation had reached $1,921,000$ (Peterson, 1964). By the 1950s, Newsweek had a circulation of 1,300,000 (Halberstam, 1979). US News and World Report's circulation did not pass one million until 1958, but it was nevertheless an influential news magazine two years prior as well (Sterling, 2009). Like other specialty magazines that gained popularity during the 1950 s, such as those that focused on sports or homemaking, these three news magazines each had their own mission: Newsweek reported important events of the week objectively and clearly, U.S. News and World Report covered on national affairs with a focus on the economy and politics, and Time used style and narrative to inform and entertain readers (Wood, 1956). The three magazines combined the latest news with literary style for which most newspapers did not have the space (Beasley, 2005). The news magazines' cumulative circulation of over 4 million suggests that many of Americas busiest people read at least one publication on a regular basis (Wood, 1956).

Compared to the newspaper articles from AP and UP, magazine articles were typically longer. There were also fewer of them because the magazines were published once a week and some covered Hungarian refugees only once or twice per issue, whereas the newspapers covered the subject up to five times a day. However, all three magazines 
paid special attention to Hungarian refugees. For example, Time named the "Hungarian Freedom Fighter" their annual Man of the Year on January 7, 1957 ("Man of the Year," 1957). Newsweek wrote several multi-paged stories about the struggles Hungarian refugees faced as they fled their homeland. The magazine also followed up with some of the families who resettled in the United States to get a better look at how they assimilated once they arrived. US News and World Report often reported on what the government was saying about the refugees.

A frame analysis examined all of the articles about Hungarian refugees published in the three magazines from November 1956 to December 1957. This chapter will show that the attribute frames from the three magazines fall into four distinct categories: refugees as typical people, refugees as escapees from communist tyranny, refugees accepted to the United States, and refugees sympathized with by Americans. As with the wire service articles, broader value frames were also examined, and in addition to the values frames that appeared in AP and UP articles, the magazines also advocated that the United States take more responsibility for the refugees.

\section{Attributes}

The process described in chapter two was also conducted for this study in order to examine and narrow down attributes used by the three magazines. After being sorted, the original attributes narrowed down to 55 attributes used 350 times in US News and World Report, 43 attributes used 228 times in Time, and 62 attributes used 324 times in Newsweek. This chapter examines the $20 \%$ most frequently used attributes from each magazine. Tables 3.1-3.3 list the most frequently used attributes of each magazine. (For a complete table of attributes, see Appendix B). Each magazine paid special attention to 
specific aspects of the Hungarian refugee crisis, but the frames of the articles overlapped substantially. This chapter combines all of the attributes but specifies which magazines they came from.

Table 3.1

Frequency of Top 20\% US News and World Report Attributes

\begin{tabular}{ll}
\hline Attribute & Frequency \\
\hline Jobs & 38 \\
Ages & 26 \\
Fled & 18 \\
Relational & 18 \\
Received Help and Supplies & 18 \\
Escapees from Communism & 17 \\
Number to Austria & 16 \\
Students & 16 \\
Accepted to the US (General) & 15 \\
Proud, Defiant, Unbroken, Extraordinary & 14 \\
Struggle to Reach Austria & 14 \\
\hline
\end{tabular}

Table 3.2

Frequency of Top 20\% Time Magazine Attributes

\begin{tabular}{ll}
\hline Attributes & Frequency \\
\hline Jobs & 22 \\
Adults (men, women) & 18 \\
Received Help and Supplies & 15 \\
Struggle to get to Austria & 14 \\
Youth & 13 \\
Negative emotion (unhappy, bewildered, & 13 \\
nervous, embittered, scarred) & 10 \\
Relational & 8 \\
Employable (skilled, trained, professional, & \\
educated) & 8 \\
Brave &
\end{tabular}


Table 3.3

Frequency of Top 20\% Newsweek Attributes

\begin{tabular}{ll}
\hline Attributes & Frequency \\
\hline Jobs & 32 \\
Received Help and Supplies & 26 \\
Youth & 23 \\
Relational & 21 \\
Students & 12 \\
Age & 11 \\
Fleeing & 11 \\
Participated in the Revolution & 10 \\
Struggle to get to Austria & 8 \\
Supported by Americans & 8 \\
Assimilating/learning English & 8 \\
Adults (men, women) & 8 \\
Supported by government officials & 8 \\
\hline
\end{tabular}

\section{Refugees as typical people}

As with the wire service articles, some of the most common attributes described who the Hungarian refugees were in terms of demographics. Time and Newsweek focused on the ages of the refugees, often reporting on young ones. Time reported about adult women and men more often than but Newsweek. All three magazines used familial roles to describe the refugees. Although Time used "father" and "wife" multiple times, Newsweek branched out when discussing the family tree and included stories about refugees" "cousins," "nephews," and "stepsons," in addition to immediate family members. US News and World Report included descriptions of "widowed" refugees, which was unique among the magazines. One article described a large bulletin board at Camp Kilmer the refugees used to locate family and friends and to trade news about who they encountered during their journey to freedom. The board was used to reach either 
refugees who had been separated from their family members during escape or Hungarians already living in the United States wondering if their family members made it to Camp Kilmer or even made it out of Hungary. The article told the story of a waitress looking for her father and cousin who lived in Hungary at the beginning of the revolution. Through the bulletin boards, a volunteer learned that the men had been spotted in Vienna, and he contacted the waitress to give her the update that her family members were safe ("The Anxious Letters," 1956). The relational terms that each magazine used not only told readers who the refugees were, but they also helped readers relate to the refugees, and reminded them that these people had families, some of whom they traveled with when they escaped and others who they had to leave behind and hope to be reunited with in the future.

Following the same framing used in the newspapers, US News and World Report commonly referred to the refugees as "students," and all three publications often referred to the jobs that refugees had held. To provide richer descriptions of the students and workers, Time and Newsweek used their lengthier articles to described refugees as “employable." Time’s descriptions included "skilled," "trained professional," and "educated" and Newsweek reported on "hard and willing workers." These descriptions were consistent regardless of the jobs that refugees found when they arrived in the United States. One article that reported on a family's quick adjustment after they arrived in the United States described two brothers, one who became a mechanic and the other who was a busboy at a casual restaurant. The former was described as "an excellent mechanic [who] is well-liked by his fellow workers," and the latter was described as "a good and willing worker" who "gives every impression of enjoying the work" ("The Fortune of a 
Family," 1957, p. 20). This focus on the employability of the refugees reminded readers that the newcomers were prepared to pull their own weight and most would not need to rely on the government for help.

\section{Refugees as escapees from communist tyranny}

Newsweek and US News and World Report frequently published stories about refugees who participated in the revolution. For example, articles in the magazine explained that the Hungarians "started their fight for freedom spontaneously after twelve years of despair and suffering" ("Incitement to Revolt," 1956, p. 23). US News and World Report focusd on the number of refugees reaching Austria and the problems caused by the influx.

One US News and World Report article explained that the Hungarians fleeing into Austria, who were costing the country $\$ 100,000$ a day, created the "biggest and most concentrated mass flight from oppression that Europe [had] seen since World War II" (“Hungary: A Nation in Flight," 1956, p. 66, 72). The reporter described Austrian families taking in refugees as soon as they crossed the border and other refugees who had been "placed in country inns and some vacant summer-resort hotels, with the Austrian government paying the bill” (p. 72). Although the magazines took different approaches to describe the background of the escapees, all three wrote about the struggles refugees faced while fleeing to Austria. The term "victim" was used less frequently than in the newspaper articles, but Time implied the same message by describing the "bedraggled and mud-soaked, footsore and soul-worn," condition of the refugees as they crossed the border into Austria ("The Huddled Masses," 1956, p. 18). 


\section{Refugees accepted to the United States}

Even though there were several different ways that the refugees' acceptance to the United States could have been categorized, US News and World Report focused on their general acceptance without going into detail about the process. Once the refugees had made it to safety, each magazine had its own way of describing the refugees so that readers could learn more about them. Newsweek focused on what the refugees were doing to assimilate in their new homeland, such as learning English or opening their own businesses. Time portrayed refugees as emotionally distressed, using adjectives such as "unhappy," "bewildered," "nervous," and "emotionally scarred." It is important to know, however, they were stating that the refugees were emotionally scarred by their experiences in Hungary, not in the United States or other countries where they sought asylum.

Time focused on negative emotions that refugees experienced, but along with US News and World Report, also described the refugees in terms of their strengths, calling them "proud," "defiant," "unbroken," "brave," and "extraordinary." For example, one US News and World Report article reported at length on the tenacity of the refugees, stating, "Most refugees come with nothing but the clothes on their backs...but their heads are held high with pride - pride not their own, but in their nation's courageous struggle" (Hungary - A nation in flight,” 1956, p. 66). By portraying refugees as emotionally vulnerable, yet proud and unbroken by the challenges they encountered, the articles indicated that Hungarian refugees were normal people who were sad to leave a homeland that they loved but brave enough to fight for freedom. 


\section{Refugees sympathized with by Americans}

Finally, all three magazines focused on what was being done to help the refugees. Time and Newsweek often reported on companies that offered jobs to skilled or experienced refugees, while US News and World Report most frequently reported on organizations and individual Americans who provided temporary and permanent housing to refugees. One article told the story of three Hungarians - a couple and their friend sponsored by a Presbyterian church near Philadelphia. The article, "New Home, New Life for Three Refugees" (1957) described the small group's experience and the help they received:

The board of deacons of that church had volunteered to sponsor the three Hungarians, guarantee $[$ sic $]$ them jobs and homes. Church members had contributed money and clothing. Two rooms normally used for Sunday-school classes were converted into living quarters. Events moved fast. In 24 hours, Joseph Garamszegi had a temporary job as a handyman around the church. Bela Kovas had a job in a supermarket. And they had found many friends. (p. 62). Other areas of help included funding, scholarships, and transportation. In addition, Newsweek often explained the ways that Americans supported or were sympathetic to the refugees. Multiple reports of sympathy came from the perspective of government officials, including Richard Nixon and Herbert Hoover. Readers may have been more inclined to accept the refugees once they read what other Americans, including a former president and vice president, were doing to help the refugees reach safety and start new lives. 
Values

US News and World Report used 10 value frames 38 times, Time used 10 value frames 79 times, and Newsweek used 11 value frames 76 times. The top five value frames from each magazine are discussed in this section. Tables 3.4-3.6 list the top five values and their frequencies.

Table 3.4

Frequency of Top Five Values Used by US News and World Report

\begin{tabular}{lc}
\hline Value & Frequency \\
\hline Economic impact of refugees - Transparency about funding refugees is important 7 \\
Economic impact of refugees - Funding refugees has positive consequence & 6 \\
Character of refugees - Refugees are good people & 5 \\
*Support for refugees - Refugees are victim patriots & 4 \\
*Support for refugees - Refugees need help & 4 \\
\hline
\end{tabular}

*Six values are listed because two frames both had a frequency of four.

Table 3.5

Frequency of Top Five Values Used by Time Magazine

Value Frequency

$\begin{array}{ll}\text { Support for refugees - Refugees need help } & 27\end{array}$

Economic impact of refugees - Funding refugees has positive consequences $\quad 14$

$\begin{array}{ll}\text { Support for refugees - Refugees are victim patriots } & 9\end{array}$

Character of refugees - Refugees are good people 9

Responsibility for refugees - The United States needs to do its share to help 5

Table 3.6

Frequency of Top Five Values Used by Newsweek Magazine

Values Frequency

Support for refugees - Refugees need help 22

Economic impact of refugees - Funding refugees has positive consequences $\quad 17$

Support for refugees - Refugees are victim patriots

Character of refugees - Refugees are good people

Economic impact of refugees - Transparency about funding refugees is important 6 
All three magazines frequently used the "Support for refugees - Refugees are victim patriots," "Support for refugees - Refugees need help," "Economic impact of refugees - Funding refugees has positive consequences," and "Character of refugees Refugees are good people" value frames. The other frames listed in the tables above were used frequently by at least two of the magazines.

With the focus of the "Support for refugees" category on information about the conflict in Hungary along with reasons that the refugees needed to be saved, the magazines spent little time reporting on people who felt that helping the refugees would be a security risk. A US News and World Report article that did include such criticism quoted Representative Francis Walter as saying, "Congress 'should proceed not promptly, but very, very carefully"” (“Eye on Refugees," 1957, p. 18). Even then he did not argue that refugees should not enter the United States, only that the government needed to investigate the options and their effects thoroughly before increasing the quota. This quotation is an example of the relatively mild pushback that was reported against the United States' decision to help the refugees.

Similarly, the magazines used the "economic impact of the refugees" value frame primarily to inform readers of the status of the economy in relation to the refugee crisis and show how helping the refugees would benefit the United States economy. The magazines seldom published articles about the negative effects on the economy of helping the refugees. One article that did include a perspective about the negative economic effects stated that a senator received a letter from citizen arguing that "we should aid the Hungarians as far as possible in helping them defend their country, but I do not feel it is right to bring them here by the thousands to take away jobs from 
Americans" ("Dear Senator," 1957, p. 53). This quotation demonstrates the fear among some American citizens that refugees would take their jobs, but several other articles explained that the refugees were filling jobs that had long been vacant, due to the high number of advanced scientists in the refugee population.

Each magazine used the "Character of refugees- Refugees are good people" value frame to describe individual refugees rather than the refugees as a group. US News and World Report described Olympic athletes on their best behavior during the Melbourne games, despite leaving family members behind in Hungary just as the revolution began and sharing Olympic facilities with Russian athletes for several weeks ("War Threats Mess Up Olympics," 1956). A lengthy Newsweek article that told the story of a group of refugees headed to the United States described one man as "polite and obviously grateful" and pointed out that the group "did not grovel," despite the long and tiring journey (“A New Life in a New World," 1956, p.16). These specific stories match the attributes that described the refugees as thankful and happy with their circumstances.

Finally, US News and World Report and Time frequently reported on the "Responsibility for the refugees- The United States needs to do its share to help" value frame. Once other countries realized that the United States was not taking in as many refugees as other countries, proportionate to their sizes ("Bridge to Freedom," 1957). Although the United States ended up taking more refugees than any country other than Austria, the United States was slow to begin accepting the refugees due to strict immigration laws that were in place at the time. Some Hungarians also said that the United States should have been doing more to help since some felt that the United States had led them to believe help was coming during the revolution, but the United States 
never intended to send its military force to Hungary to confront the Soviets. This push for the United States to assist the refugees led President Eisenhower to advocate for increased refugee quotas. 


\section{CHAPTER IV}

\section{NEW YORK TIMES COVERAGE}

The third frame analysis examined articles from the New York Times, an influential newspaper at the time of the 1956 Hungarian Revolution. In 1951, the year of the publication's $100^{\text {th }}$ anniversary, the The New York Times was considered by many to be the most complete and accurate news publication in the United States (Berger, 1951). By 1956, its reporters had already received 25 Pulitzer Prizes (Pulitzer Prize, 2016).

In 1927, the New York Times became the first newspaper to include an index of each issue, thus becoming the "newspaper of record" (Okrent, 2004). In the 1950s the publication's goal was to print all of the day's most important information in the format of "announcements, schedules, directories, and transcripts" (p. 1). Furthermore, the newspaper's headquarters was fairly close to Camp Kilmer, New Jersey, the processing location for all Hungarian refugees entering the United States, so the Times frequently reported on the arrival of Hungarian refugees and followed up as they were resettled.

This chapter analyzes and discusses the presence and frequency of attributes and values found in articles published in the New York Times from November 1956 to December 1957. During this time period, the New York Times published 803 articles about Hungarian refugees. Because this number is significantly higher than the sample size used in the previous two chapters, the articles were arranged in chronological order, and every fourth article was examined, resulting in a systematic sample of 200 articles. 
Whereas the AP and UP articles were mostly short reports, and the magazine articles were longer, articles from the New York Times were a mixture of all lengths.

This chapter will show that the most common New York Times attribute frames fall into four distinct categories: demographics, reasons for leaving Hungary, the journey to freedom, and life in the United States. Like wire service and magazine articles, the New York Times articles also used broader value frames to inform readers of the impact on the economy, advocate for helping the refugees, and tell positive stories about specific refugees to help readers get to know the newcomers.

\section{Attributes}

After sorting through the original findings and combining similar attributes, there were 124 unique attributes used 1557 times. As in the previous chapters, the attributes were sorted by frequency, and the most frequently used $20 \%$, shown in Table 4.1 , are discussed in this chapter. (For a complete list of attributes, see Appendix E).

\section{Table 4.1}

Frequency of Top 20\% of New York Times Attributes

\begin{tabular}{ll}
\hline Attribute & Frequency \\
\hline Received help and supplies & 161 \\
Youth & 100 \\
Jobs (total) & 96 \\
Number to Austria & 68 \\
Accepted by other countries & 64 \\
Problem/need & 54 \\
Assimilating/learning English & 53 \\
Relational & 51 \\
Ages & 50 \\
Fled & 44 \\
Struggle to get into Austria & 43
\end{tabular}


Procedure/processes

Accepted by the US (general) 34

Welcomed/greeted 31

Participated in the revolution 30

Conditions in Hungary (negative) 29

Unhappy with circumstances 27

Found/searched for freedom/haven/safety $\quad 26$

Adults 26

Victim (imprisoned, tortured, oppressed,

persecuted) 24

Escapees 22

Flown to the US 18

Freedom fighter 18

Positive description (Finest people in Hungary, not the huddled masses, best, generally favorable, magnificent, eager to learn, independent, valuable, vigorous, outstanding, talented, ambitious) $\quad 18$

Number in Yugoslavia $\quad 16$

Reconnected with relatives $\quad 15$

Supported by the Red Cross 15

Want to come to the US 15

\section{Demographics}

Like the news outlets studied in chapters two and three, the New York Times incorporated a large amount of demographic information about the refugees into its articles so that readers could learn who the refugees were. When covering various families, The New York Times branched out further than the wire services and magazines and discussed refugees as uncles, nephews, grandsons, and grandparents, in addition to immediate family members. The articles discussed people of all ages including babies, middle aged people, and the elderly, but they covered young people the most.

Many of the articles about young people focused on their contributions to the revolution. One article described students still wearing their green, white, and red armbands, a symbol of the revolution, when they crossed the border into Austria. Other 
New York Times articles focused on the young people's attempts to continue their schooling as they fled from Hungary. Half of the students from Hungary's Sopron University left their homeland together, and Austria set up accommodations for them to continue their studies soon after they arrived. This focus on the determination and seriousness of the young Hungarians as portrayed by the New York Times may have alleviated readers' potential concern that they would have to take care of helpless children who were escaping the violence in Hungary if refugees were accepted to the United States. The articles made it clear that many of the young people leaving Hungary left only because their lives were in danger after they participated in the revolution, and all they wanted was continue live in safety.

\section{Reasons for leaving Hungary}

Another frame used by the New York Times went into detail about what warranted the refugees to flee their homeland. The publication described the dangerousness of Hungary with details about the revolution and what was happening to many who opposed the communist government. Because the New York Times offices were located near Camp Kilmer, New Jersey, where most of the refugees who came to the United States were first taken to be processed, the publication often reported stories straight from the refugees about their experiences during the revolution. Articles described "barbarous oppression" experienced by "victims of Soviet aggression" (Waggoner, 1956, p. 3; "Drive gets $\$ 150,000$ in month to assist Hungarian refugees," 1957, p. 7). Others explained that freedom fighters left work or school and started fighting the Russian soldiers in the streets with homemade bombs and any guns they could find when the revolution began. 
Then many of the rebels and their families fled Hungary after the Soviets returned and began to crush the revolt and deport, arrest, and torture those who participated in the uprising.

\section{The journey to freedom}

In addition to explaining why refugees left their homeland, the New York Times also detailed the journeys of refugees who left Hungary. One article implied the severity of the problem in Hungary by stating that the refugees "risked life and security to escape communism" (Frankel, 1957, p. 152). The dangerous and oppressive conditions led many to leave their homes and sometimes their families and risk an escape attempt. Like AP, UP, and the news magazines, the New York Times chronicled the refugees' struggles to get into Austria and the high numbers at which they arrived.

Unlike the other publications, however, the New York Times also mentioned that there was a point at which just as many refugees were fleeing to Yugoslavia as to Austria. The articles explained that eventually there were so many Russian soldiers and Hungarian police at the Hungarian-Austrian border that it became almost impossible for the Hungarians to escape to Austria. Once word spread that fleeing to Austria was no longer an option, many refugees headed for Yugoslavia. This decision was risky for the refugees because Yugoslavia was a communist country, and at first many refugees were unsure if they would be allowed to stay there safely or if they would be turned over to the Hungarian police. The New York Times explained that by the end of January, reports were being received that "safer and proper treatment awaits fugitives in Yugoslavia" (Frankel, 
1957, p. 8). Then refugees began to enter Yugoslavia even faster than they were getting to Austria.

The refugees' worries were not necessarily over once they made it to Austria or Yugoslavia. The New York Times focused on the problems that occurred while refugees awaited acceptance to other countries. Several articles reported about refugees who were unhappy with their circumstances after risking everything to get out of Hungary. Reported problems included inadequate housing in Austria, lack of funds to take care of refugees in Yugoslavia, and massive red tape for the refugees who wanted to go to the United States.

The articles explained that the refugees were upset to learn that they had to stay at the camps in Austria and Yugoslavia up to five months if they wanted to come to the United States (MacCormac, 1957). This disappointment was attributed to the fact that Radio Free Europe, a United States government-funded radio station that aired anticommunist propaganda in Hungary, implied that the United States government supported an uprising in Hungary, so the refugees thought the United States would help them immediately if they rebelled. In reality, Radio Free Europe may have spoken more on emotion than facts and misrepresented the plans of the United States government. Although other countries accepted refugees if they wanted to come, many refugees believed that if they left Austria, they would no longer be considered for immigration to the United States. The refugees who preferred to wait in Austrian camps until the United States accepted them desired to come to the United States for safety and the "American Dream." One article explained that many hoped to come to the United States because they feared that if they stayed in Europe, they could be tracked down by communists and 
punished for escaping or participating in the revolution (Weart, 1956). Other refugees, enticed by the "American Dream," were determined to come to the United States for well-paying jobs and nice homes that they did not have in communist Hungary.

Therefore, some waited in camps for months before deciding to look for freedom in another country or even returning to Hungary to face their fate for participating in the revolution. In August 1957, the New York Times reported that 2500 refugees had returned to Hungary "in full knowledge of the hazard they run is a measure of their despair of receiving promised asylum in the West" (Salisbury, 1957, p. 14).

The New York Times articles tended to report on the Hungarians' struggles using a critical approach that may have stirred stronger emotions in readers, urging them to help the refugees or at least support their acceptance to the United States. One New York Times article explained that Western nations' unorganized attempts to help refugees had resulted in "relief supplies [that] poured in helter-skelter - too many old shoes, not enough underwear" (Frankel, 1957, p. 152). The article also argued that the United States had a history of both "encouraging and discouraging escape at the same time and treating refugees sometimes magnanimously and sometimes coldly... often leading to confusion, misery, and bitterness" (p. 152). The publication made it clear that the refugees wanted to come to the United States so they could continue with their lives, not to sit around and be pitied by Americans, but to contribute to the country where they sought freedom.

\section{Life in the United States}

Although there was a sometimes difficult red tape and strict regulations to get through to come to the United States, approximately 35,000 Hungarian refugees 
eventually made it. The final frame that the New York Times used described the experiences of refugees who made it to the United States. Like the other publications, the New York Times most often reported on refugees who were accepted to the United States in general terms instead of specifying whether they received a visa or were accepted as parolees.

Attributes for refugees who flew or sailed to the United States were overwhelmingly positive. Articles described the happy welcome that refugees received when they arrived to Camp Kilmer. Along with being greeted by their new New Jersey neighbors, government officials, and priests from nearby churches, some lucky refugees were reconnected with family members as they arrived in the United States. One article, which told of a group of refugees who left Camp Kilmer to settle in Detroit, reported that they were greeted by 2,000 people at the airport, most of whom were of Hungarian heritage.

Other articles highlighted the support refugees received from relief agencies, none of which did more than the Red Cross. Journalists reported on clothing drives and fundraisers planned by the organization. Plenty of smaller organizations and individuals also offered help and supplies to the refugees. The New York Times most often reported that refugees were receiving offers of jobs, free flights to their final destinations in the United States, and scholarships for students.

The refugees were described in such a positive way that it is no surprise they received so much help adjusting to life in the United States. The New York Times described the newcomers as the "finest people in Hungary," the "best," "valuable," "vigorous," "magnificent," and "ambitious." Expanding on comparisons to other refugee 
or minority groups, one article described the refugees as "not the huddled, storm-tossed masses, yearning for relief from the quarrels and oppression of Europe" (Abel, 1956, p. 245).

Finally, like the other sources, the New York Times frequently described the efforts that refugees were making to assimilate in the United States. Many who experienced a language barrier when they first arrived quickly accepted offers of English classes at universities and community centers in the towns where they resettled. Some Hungarian musicians who came to the United States formed an orchestra and performed around the country. One Hungarian who got a job as a butcher in a grocery store informed his boss that he wanted to host a party to thank everyone in the town for their kind welcome. Another man joined a yacht club in order to better understand American customs. According to the New York Times, the vast majority of Hungarians who came to the United States wasted no time getting acquainted with their new homes, jobs, neighbors, and traditions.

The positive way that the New York Times described the Hungarian refugees would have influenced public opinion about the refugees. The readers learned how hard the refugees fought to get to the United States, and the newspaper made it sound like being here was their dream come true. Almost all of the refugees interviewed were happy to work hard, were thankful for their freedom, and just wanted to fit in and live like typical Americans.

\section{Values}

The New York Times articles were also examined from the lens of broader value frames. Ten values frames were found 339 times within 200 articles in the representative 
sample. The top five value frames will be discussed in this section. Table 4.2 lists the top five values and their frequencies.

\section{Table 4.2}

Frequency of Top Five New York Times Values

Value

Frequency

Economic impact of refugees - Transparency about funding refugees is important 103

Support for refugees - Refugees need help 50

Economic impact of refugees- Funding refugees has positive consequences $\quad 49$

Character of refugees - Refugees are good people

Support for refugees - Refugees are victim patriots

The value frames the New York Times used most frequently are consistent with those of the other publications. The "economic impact" category most often provided transparent information about funds received by refugees and explained why funding or helping the refugees would have positive economic consequences. Present in one-third of the articles, "Economic impact of refugees - Transparency about funding refugees is important" was by far the most frequently used value frame in New York Times. In general, such articles informed readers about how much money the government was using to fund the refugees, both overseas as they waited in Austria and Yugoslavia and in the United States as they were getting settled.

The articles that used the "Economic impact of refugees- Funding refugees has positive consequences" frame primarily argued that by funding educated and skilled refugees, the United States would be gaining productive members of society. Again, reporters often wrote from the perspective of people who believed that Hungarians were superior to other immigrant groups, such as Mexicans, and would not be a liability to the 
United States economy. This point of view may have been one of the primary lessons learned by Americans who read the New York Times.

Similar to the "economic impact" frame, the "support for refugees" frame was used to distribute information about the plight of the Hungarians or advocate for saving the refugees from communist oppression. The articles that shared information about the conflict in Hungary had a way of advocating for the Hungarians without doing so directly. For example, one article reported that Hungarian Red Cross workers in clearly marked ambulances and hospitals were purposely killed by Russian soldiers ("Red Cross Aides Killed,” 1956, p. 20). A report of such ruthless acts likely made readers feel that what was happening to the Hungarians was ruthless.

Other articles directly reported perspectives of people who believed the Hungarians deserved to be saved from their conflict with the Russians. One article reported that the Interior Minister of Austria "appealed to the United Nations High Commission for Refugees to help in dealing with the flood of refugees." The same article described an Austrian government leader who was reportedly said, "The defeat of the uprising in Hungary. . . plunged all Austrians into an abyss of sadness" (Hoffman, 1956, p. 18). Reports of desires to help the Hungarians did not come just from Europe, but the United States as well. One article reported that 29 states signed on to designate November 25, 1956 as "Help Hungary Day." The article reported that by just one month after the revolution began, 723 organizations and individuals in the United States had contacted the office of the International Rescue Committee to offer jobs, housing, or child care to Hungarians who were accepted to the United States ("29 States Will Observe, 'Help Hungary' Sunday,” 1956, p. 2). These reports and others from Austria, 
the United States, and other parts of the world made it clear that many people had found room in their hearts to help the Hungarians, and as a result, many readers would find room in their homes and money in their wallets for them as well.

Finally, the "Character of refugees - Refugees are good people" frame highlighted the good things that specific refugees were doing. A longer article that detailed the new lives of Hungarians living in Milwaukee labeled the group a "success story." The journalist reported that the refugees "are almost fiercely independent in spirit, eager to learn everything, [and] impatient if they can't get on quickly because of language difficulties" (Samuels, 1957, p.138). Like the other value frames, the personalization frame continues the message that the refugees did not come to the United States to be taken care of, but only to have the freedom to work hard and take care of themselves.

The same article summarized the experiences of many Hungarian refugees who came to the United States, reporting, "By now, most of the skilled and the unskilled workers have found their level and have been so rapidly absorbed that they are no longer news in the local press" (Samuels, 1957, p.138). This update indicated that by mid-1957, the Hungarians who had arrived in the United States had settled in and gotten to work. It was business as usual in their new hometowns. Articles about refugees taking Americans' jobs or committing crimes were scarce, and the majority of reports made it clear that as long as they did their part, the refugees were welcome across the United States. 


\section{CHAPTER V}

\section{CONCLUSION}

The wire services, news magazines, and the New York Times consistently framed Hungarian refugees in a positive manner from November 1956 to December 1957, which matched the American public opinion of refugees. AP and UP wire services framed refugees as typical people, victims in need of help, newcomers to America, and oppressed people who escaped oppression. The wire services also used broader value frames that exposed readers to information about support being given to refugees and why it was needed and deserved, the economic impact of the refugees, and the positive character of individual refugees. Similar to the wire services, US News and World Report, Newsweek, and Time described refugees as typical people, escapees from communist tyranny, newcomers to the United States, and people who Americans sympathized with and accepted. The magazines urged the United States to take more responsibility for the refugees. Finally, the New York Times described the refugees as typical people, victims who were forced to leave Hungary, anti-communists who sought freedom, and newcomers who thrived in the United States. The New York Times informed readers of the impact of Hungarian refugees on the economy, advocated for helping refugees, and told positive stories about specific refugees to help readers get to know the newcomers.

Although the writing styles and political leanings of the news outlets varied, most of the published stories would have encouraged readers to pity the Hungarian 
refugees, help them, and accept them. Of course there were refugees who did bad things or were secretly communist, but the news media rarely reported about them. Instead they focused on the struggle of the victims of communism, and how hard they worked to reach freedom and safety.

However good, productive, and brave the Hungarian refugees may have been, it is likely that American reporters related to the Hungarian refugees because the revolution that they started indicated that they felt the same way about freedom and anticommunism as most Americans felt. Therefore, the media portrayed them that way and American readers felt sympathetic towards Hungarians in the same way that they would have felt sympathetic towards their fellow countrymen.

The majority of Americans approved of the government's plan to accept Hungarian refugees and many helped them start new lives in the United States. Although this thesis is an examination of media framing, not media effects, the frames are in line with American public opinion about refugees. In addition to the public relations campaign advocated by Eisenhower, the media illustrated to Americans that Hungarian refugees were good, productive people who had been victimized by the enemy and deserved help. It is possible these frames influenced the public opinion that favored the refugees in this circumstance.

The ways news media did not frame the Hungarians are also important. Although articles were used in this thesis if they included the words "refugee" or "immigrant," few of the articles refer to the Hungarians as immigrants. In fact, in all of the articles studied, reporters called the Hungarians "immigrants" only six times. This consistent distinction may have played a role in the formation of public opinion about the Hungarians. The 
media labeled them as people with a "well-founded fear of persecution for reasons of ... political opinion" as the United Nations High Commissioner for Refugees defined the classification in 1951. If the new sources used "immigrant" more often to described the Hungarians, readers may have felt less inclined to support the Hungarians because the term implies that the individuals have the option of staying in their homeland, thus receiving less pity from Americans.

Examining how news media frame refugees is important because the frames are being used to inform media consumers about some of the world's most vulnerable people. If refugees are being framed as innocent victims who are similar to Americans, it is likely that American readers will want to accept and help them. On the other hand, if the refugees are described as significantly different, it is possible that readers will think of them as scary. If the refugees are feared, then Americans are less likely to help them, even if they are still victims in dangerous situations.

This distinction can mean life or death for refugees who are attempting to escape war or persecution. It can also mean the difference between Americans urging the government to accept and help refugees quickly and Americans urging the government to act carefully and slowly. The latter can put refugees in limbo for years. In the Hungarian case, the camps were closed by the end of 1958 because all of the refugees had received an outpouring of support and acceptance from around the world, so the camps were no longer necessary. Establishing trends of media frame usage during times of crisis, may make predicting whether a refugee group will be accepted or scorned easier. 


\section{Future research and limitations of study}

One major criticism of frame analyses is their subjective nature. They are open to broad interpretation. The same frames can be coded differently by multiple researchers. This thesis used an additional systematic and empirical method. By using attributes, as this thesis did, words and messages were pulled straight from the news articles and were used to create the frames. Value frames are beneficial, which is why they were still used in this thesis. Relationships and similarities between the attributes and value frames can be seen. Future researchers may consider uses attributes to examine news frames as a way to eliminate some of the criticism that the method receives by being more systematic and empirical.

Another strength of this research was the usage of triangulation by examining frames used by multiple news media. Many frame analyses examine one or two sources, which may not produce an exhaustive conclusion about how the media framed a topic. Because most consumers are exposed to multiple media, it makes sense to take a broader look at the content they use.

One methodological limitation of this study was the choice to examine only wire service articles found in regional newspapers and not including articles published only in local newspapers. This method excluded articles written by reporters from different regions of the United States. Therefore, it was not possible to compare perspectives of regional newspapers. For example, every time a new group of Hungarian refugees arrived in Louisville, Kentucky, the Courier-Journal published an in-depth article, telling readers who the refugees were, what their backgrounds were, how they had struggled, and who was taking care of them. The other two newspapers published highlights about a few 
groups of refugees arriving in Cedar Rapids and Eugene, but they did not go into detail nearly as often. Other regional newspapers in the United States may have had different ways of describing the refugees. Future research examining the frames used by newspapers around the country might reveal how newspapers across the country reported on Hungarian refugees differently.

Another limitation of this thesis is that it describes only some of the news outlets that published reports about Hungarian refugees. For example, communist publications may have described Hungarian refugees from a negative perspective. Although the news outlets included in this thesis were the most popular news media of the 1950s, there were others that can be examined to determine what less popular media outlets reported about the Hungarian refugees.

Public opinion of refugee groups may not be fully formed within one year of a crisis. Opinions about groups may change over time based on ever-evolving politics, economical impact, and the behavior of the refugees. Future research on news frames about Hungarian refugees should examine whether the frames changed the longer the refugees were in the United States or if articles about Hungarians stopped being published for the most part. In other situations, Americans were initially reluctant to accept refugee groups, but eventually the refugees proved not to disrupt life and blended in with the rest of society. Because the media painted the Hungarian refugees in such a positive way, making them seem like innocent people who wanted nothing more than to work hard and contribute to their new country, it is possible that some Americans who interacted with the less ambitious individuals in the group would have been disappointed by reality. 
Finally, the case of Hungarian refugees is a snapshot of how the media framed one refugee group in 1956 and 1957. Future research to examine how the media have framed other refugee groups could provide a broader understanding of the link between media framing and public opinion of refugees throughout American history. The United States' relationship with refugees has been complicated, but an examination of how the media framed refugee groups before and after 1956-57 may increase our understanding of the role that news media play in American public opinion formation about refugees. 


\section{REFERENCES}

29 States will observe, 'Help Hungary' Sunday. (1956, November 23). New York Times, p. 2.

300 refugee arrivals due in US daily. (1956, December 2). Eugene Register-Guard, p. $2 \mathrm{~A}$.

800 crimes against refugee homes reported this year. (2016, October 19). The Local. Retrieved from https://www.thelocal.de/20161019/800-attacks-against-refugeehomes-reported-this-year/

Abel, E. (1956, November 25). Out of Hungary - The defiant exiles. New York Times, p. 245.

The anxious letters. (1956, December 17). Newsweek, p. 42.

Austrian police kill Russian inside border. (1956, November 24). The Courier-Journal, p. 1.

Baughman, J. L. (1993). Television comes to America, 1947-1957. Retrieved from http://www.lib.niu.edu/1993/ihy930341.html/

Beasley, M. H. (2005). The emergence of modern media: 1900-1945. In W. D. Sloan (Ed.), The Media in America: A History (p. 283-302). Northport, AL: Vision Press.

Berger, M. (1951, September 17). The Gray Lady reached 100. Life, p. 153.

Berns, N. (2004). Framing the victim: Domestic violence, media, and social problems. Hawthorne, N.Y.: Aldine de Gruyter. 
Bon Tempo, C. J. (2008). Americans at the gate: The United States and refugees during the Cold War. Princeton: Princeton University Press.

Bridge to freedom, (1957, February, 11). Time, p. 28.

Brinson M.E., \& Stohl M. (2012). Media framing of terrorism: Implications for public opinion, civil liberties, and counterterrorism policies. Journal of International and Intercultural Communication, 5(4), 270-290.

CBS News/New York Times poll. (1994, September 8). CBSNews.com, Retrieved from http://www.cbsnews.com/news/cbs-news-poll-database/

Chong, D., \& Druckman, J. N. (2007). A theory of framing and opinion formation in competitive elite environments. Journal of Communication, 57(1), 99-118.

Conner, P. (2016, December 15). International migration: Key findings from the U.S. Europe, and the world. Pew Research Center. Retrieved from http://www.pewresearch.org/fact-tank/2016/12/15/international-migration-keyfindings-from-the-u-s-europe-and-the-world/

Conway, G. (1997) Islamophobia: A challenge for us all. Great Britain: The Runnymede Trust.

Coriden, G. E. (1994). Report on Hungarian refugees. Retrieved from https://www.cia.gov/library/center-for-the-study-of-intelligence/kentcsi/vol2no1/html/v02i1a07p_0001.htm

Dear senator. (1957, February, 22). US News and World Report, p. 53.

Desilver, Drew. (2015, November 19). U.S. public seldom has welcomed refugees into country. Pew Research Center. Retrieved from http://www.pewresearch.org/facttank/2015/11/19/u-s-public-seldom-has-welcomed-refugees-into-country/ 
De Vreese, C. H. (2005). News framing: Theory and typology. Information Design Journal and Document Design, 13(1), 51-62.

Drive gets $\$ 150,000$ in month to assist Hungarian refugees. (1957, January 6). New York Times, p. 7.

Emery, M., Emery, E., \& Roberts, N. L. (2000). The press and America: An interpretive history of the mass media (9th ed. ed.). Boston: Allyn \& Bacon.

Entman, Robert M. (1993). Framing: Towards clarification of a fractured paradigm. Journal of Communication, 42(4), 51-58.

Entman, R. M. (2007). Framing bias: Media in the distribution of power. Journal of Communication, 57(1), 163-173.

Erwin, R. (1953, June 6). New AP style book changes newspaper copy very soon. Editor \& Publisher, p. 9.

Eye on refugees. (1957, February, 1). US News and World Report, p. 18.

Fantz, A. \& Brumfield, B. (2015, November 19). More than half the nation's governors say Syrian refugees not welcome. CNN.com. Retrieved from http://www.cnn.com/2015/11/16/world/paris-attacks-syrian-refugees-backlash/

Federation for American Immigration Reform (2008). History of U.S. immigration laws. Retrieved from http://www.fairus.org/facts/us_laws/

Fiske, S. T., \& Taylor, S. E. (1991). Social cognition (2nd ed.). New York: McGrawHill.

Flick, U. (2004). Triangulation in qualitative research. A companion to qualitative research, 178- 183.

The fortune of a family, (1957, May 20). Newsweek, p. 20. 
Frankel, M. (1957, January 25). Yugoslavia gets most refugees. New York Times, p. 8.

Frankel, M. (1957, February 3). Refugees confront U.S. with basic decisions. New York Times, p. 152.

Gallup, G. (1972). The Gallup Poll public opinion 1935-1972. New York: Random House.

Gallup, G., \& Robinson, C. (1938). American Institute of Public Opinion-Surveys, 193538. The Public Opinion Quarterly, 2(3), 373-398.

Goffman, E. (1974). Frame analysis: An essay on the organization of experience. Cambridge, MA: Harvard University Press.

Granville, J. C., \& Garthoff, R. L. (2004). The first domino: International decision making during the Hungarian crisis of 1956 (1st ed.). College Station: Texas A\&M University Press.

Halberstam, D. (1979). The powers that be (1st ed.). New York: Alfred A. K.

Help the Hungarians. (1956, December 10). Cedar Rapids Gazette, p. 2.

Higher refugee quota urged. (1956, December 13). Eugene Register Guard, p.14.

Hoffman, P. (1956, November 5). Hungarians flee forces of Soviet. New York Times, p. 18.

The huddled masses. (1956, December 3). Time, p. 18.

Hungarian refugees make good in a hurry. (1957, March 3). Cedar Rapids Gazette, p. 5. Hungarians thirst for US schools. (1956, December 12). Eugene Register Guard, p.12. Hungary: A nation in flight, (1956, December 7). US News and World Report, p. 66, 72. Hungary closes gaps to refugees. (1957, January 9). The Courier-Journal, p.12. 
Igielnik, R. \& Krogstad, J. M. (2017, February 3). Where refugees to the U.S. come from. Pew Research Center. Retrieved from http://www.pewresearch.org/fact$\operatorname{tank} / 2017 / 02 / 03 /$ where-refugees-to-the-u-s-come-from/

Incitement to revolt. (1956, November 26). Newsweek, p. 23.

Job help for refugees: U.S. will assist New York in interviewing Hungarians. (1956, November 22). New York Times, p. 3.

Jones, J. M. (2015) Americans again opposed to taking in refugees. Retrieved from http://www.gallup.com/poll/186866/americans-again-opposed-takingrefugees.aspx.

Krebs, A. (1982, June 3). United Press International: Reputation of always being a very lively no. 2. New York Times. Retrieved from http://www.nytimes.com/1982/06/03/us/united-press-international-reputation-ofalways-being-a-very-lively-no-2.html

Kuypers, J. A. (1997). Presidential crisis rhetoric and the press in the post-cold war world. Westport, Conn.: Praeger.

Latest hate crime statistics released. (2016). FBI.gov. Retrieved from https://www.fbi.gov/news/stories/2015-hate-crime-statistics-released/ Library of Congress (2013). Library Announces National Recording Preservation Plan. Retrieved from https://www.loc.gov/item/prn-13-014/

MacCormac, J. (1957, April 19). Refugees oppose Austria as home. New York Times, p. 8.

Man of the year. (1957, January 7). Time. Retrieved from http://content.time.com/time/covers/0,16641,19570107,00.html. 
McCombs, M., Shaw, D. L., \& Weaver, D. (1997). Communication and democracy:

Exploring the intellectual frontiers in agenda-setting theory. Mahwah, NJ: Erlbaum.

Mevius, M. (2005). Agents of Moscow: The Hungarian Communist Party and the origins of socialist patriotism, 1941-1953. Oxford: Clarendon.

Mickelson, S. (1957). Growth of television news, 1946-57. Journalism Quarterly, 34(3), 304.

Morey, P., \& Yaqin, A. (2011). Framing Muslims: Stereotyping and representation after 9/11. Cambridge, Mass.: Harvard University Press

Muslim Americans: No signs of growth in alienation or support for extremism. (2011, August 29). Pew Research Center. Retrieved from http://www.pewresearch.org/daily-number/muslim-americans-no-signs-ofgrowth-in-alienation-or-support-for-extremism/

Nemes, P. (1999). The welcome refugees: Why the West opened its armed to fleeing Hungarians in 1956. Central Europe Review, 19(1). Retrieved from http://www.ce-review.org/99/19/nemes19.html/

New home, new life for three refugees. (1957, January 4). US News and World Report, p. 62.

A new life in a new world. (1956, December 24) Newsweek, p.16.

The 1956 Hungarian Revolution as depicted in newsreels. (2007). Retrieved from https://archive.org/details/1956_Hungarian_Revolution_as_Depicted_in_Newsree 1s.

Oatis, W. N. (1953, September 21). Why I confessed. Life, p. 131. 
Ogilvie, S. A., \& Miller, S. (2006). Refuge denied: The St. Louis passengers and the Holocaust. Madison, Wis.: University of Wisconsin Press.

Okrent, D. (2004, April 25). The public editor: Paper of record? No way, no reason, no thanks. New York Times. Retrieved from http://www.nytimes.com/2004/04/25/weekinreview/the-public-editor-paper-ofrecord-no-way-no-reason-no-thanks.html?_r=0/

Peterson, T. (1964). Magazines in the twentieth century (2d ed.). Urbana: University of Illinois Press.

Price, V., \& Tewksbury, D. (1997). News values and public opinion: A theoretical account of media priming and framing. In G. A. Barnett \& F. J. Boster (Eds.), Progress in the communication sciences Vol. 13, p. 173-212). New York: Ablex. Pulitzer Prize (2016). Retrieved from http://www.nytco.com/pulitzer-prizes/

Red cross aides killed. (1956, November 7). New York Times, p. 20.

Reds reportedly rob, kill Hungarian refugee. (1957, January 12). The Courier-Journal, p. 17.

Riles, J. M., Sangalang, A., Hurley, R. J., \& Tewksbury, D. (2015). Framing cancer for online news: Implications for popular perceptions of cancer. Journal of Communication, 65(6), 1018-1040.

Safe but not happy. (1956, November 19). The Courier-Journal, p.2.

Salisbury, H. E. (1957, August 21). Young refugees long for America. New York Times, p. 14.

Samuels, G. (1957, July 7). Hungarian exiles. New York Times, p.138. 
Sebestyen, V. (2006). Twelve days: The story of the 1956 Hungarian Revolution. New York: Pantheon Books.

Shamir, J., \& Shamir, M. (2000). The anatomy of public opinion. Ann Arbor: University of Michigan.

Sterling, C. (2009). Encyclopedia of journalism. Thousand Oaks, Calif.: Sage Publications.

Teglas, C. (1998). Budapest exit: A memoir of fascism, communism, and freedom (1st ed.). College Station: Texas A\&M University Press.

United Nations High Commission for Refugees (1951, July 28). Convention Relating to the Status of Refugees. Geneva: UN General Assembly.

United Nations High Commission for Refugees (2006, 1 October). The 50th Anniversary of the Hungarian Uprising. Retrieved from http://www.unhcr.org/enus/news/editorial/2006/10/452665e92/refugees-magazine-issue-144-hungarianrefugees-50-years-editorial-50th.html/

United States Department of State. (2015). Cumulative Summary of Refugee Admissions. Retrieved from https://www.state.gov/j/prm/releases/statistics/251288.htm.

United States Department of State, United States Department of Homeland Security, and United States Department of Health and Human Services. (2015). "Proposed Refugee Admissions for Fiscal Year 2016: Report to the Congress.” Retrieved from https://www.state.gov/documents/organization/247982.pdf. 
United States Holocaust Memorial Museum. (2017). United States policy and its impact on European Jews. Retrieved from https://www.ushmm.org/wlc/en/article.php?ModuleId=10007652/

United States Holocaust Memorial Museum. (2017). Voyage of the St. Louis. Retrieved from https:/www.ushmm.org/wlc/en/article.php?ModuleId=10005267/

Valkenburg, P. M., Semetko, H. A., \& De Vreese, C. H. (1999). The effects of news frames on readers' thoughts and recall. Communication Research, 26(5), 550-569.

Waggoner, W. H. (1956, November 10). British protest failure of Soviet to curb disorder at Embassy. New York Times, p. 3.

War threats mess up Olympics. (1956, November 23). US News and World Report, p. 56.

Weart, W. G. (1956, December 22). Refugees called proud, spirited. New York Times, p. 3.

Weinstock, S. A. (1970). Acculturation and occupation: A study of the 1956 Hungarian refugees in the United States (Publications of the Research Group for European Migration Problems, 15; Publications of the Research Group for European Migration Problems, 15). The Hague: M. Nijhoff.

What price freedom? (1956, November 22). The Cedar Rapids Gazette, p. 2.

White House statement: Total put at 200,000. (1957, December 29). New York Times, p. 12.

Wood, J. P. (1956). Magazines and the United States. (2d ed.). New York: Ronald Press. 


\section{APPENDICES}

Appendix A

Frequency of AP Attributes

\begin{tabular}{ll}
\hline Attribute & Frequency \\
\hline Received Help and Supplies & 134 \\
Youth & 128 \\
Relational & 122 \\
Struggle to get into Austria & 112 \\
Jobs & 86 \\
Ages & 85 \\
Supported by a Government Official & 67 \\
Fled & 66 \\
Assimilating/Learned English & 62 \\
Arrived by Ship or Air to the US & 54 \\
Victims of Soviet Oppression & 50 \\
Adult/Men/Women & 46 \\
Number to Austria & 46 \\
Accepted to the US (General) & 45 \\
Problem/Need & 45 \\
Welcomed & 42 \\
Accepted to Other Countries & 41 \\
Procedures/Processes & 41 \\
Student & 36 \\
Feared for Family Still in Hungary & 33 \\
Shot by Russians & 32 \\
Found/Sought Freedom/Safety/Haven & 31 \\
Escapees & 27 \\
Positive Emotion (Cheerful, Excited, & \\
Hopeful, Joyful, Merry, No Weeping & 26 \\
and Wailing, Smiling) & 24 \\
Participated in the Revolution & 22 \\
Unhappy with their circumstances & 21 \\
Conditions in Hungary (negative) & 18 \\
Conditions in Camps (positive) & \\
Religious (Baptist Minister, Cardinal, & \\
Catholic, Evangelical, Jesuit Seminary & \\
Student, Jewish, Protestant, Reverend & 17 \\
Sent back to Austria/Hungary & 15
\end{tabular}


Thankful 14

Anti-Communist 13

Group 13

Negative Emotion (Anxious, Crying,

Grief-stricken, Nervous and Strained,

Weary)

21,500 Arriving to the US 12

Conditions in Camps (Negative) 12

Positive Descriptions (Courageous,

Determined)

Positive Description for Jobs

(Skilled, Qualified, Productive,

Intellectuals, Employable, The Stuff

Out of Which Great Americans Are

Made)

Reconnected with Relatives 12

Returned to Hungary (Neutral) 12

Sponsored 12

Has Goals/Aspirations $\quad 11$

Rebel 11

Sponsored by a Religious Affiliation $\quad 11$

Supported by the Red Cross 11

Wants to go to the US 11

Freedom Fighter 10

Fugitives from oppression 10

Sad Physical Description (Cold

and Weary, Exhausted, Foot-Sore,

Looking Far Older Than his Years,

Lost Looking, Weary, Wide Eyed) 10

Misbehaved (Hauled off to Jail by Vienna

Police, Attacked Communist Newspaper,

Charged with Disorderly Conduct,

Demonstrating Without Police Permission,

Fist Fights Broke Out, Injured Communists

in Chile, Rioting, Smashed Tables and

Chairs)

Accepted to the US (Parolees) 8

Criticized by a Government Official 8

Members of the Hungarian Army 7

Crippled 7

Newcomers 7

Positive Physical Description

(Good-Looking, Hardy, Powerfully-Built,

Pretty, Slim with Grey Hair, Pretty,

Ruggedly Handsome, Sturdy,

Vivacious Blonde) 
Chose Not to Return to Hungary 6

Received Sympathy from the US 6

Visited by Nixon 6

Accepted to the US (Visas) 5

Communist 5

Language Barrier 5

Want to return to Hungary (Miss Family) 5

5,000 to be Admitted to the US 4

Does Not Know Anyone in the US 4

Hungry 4

Looking for a Job 4

Neutral Physical Description (Sandy

Haired, Short, Plump, Bespectacled, Tall) 4

Positive Effect on the US Economy 4

Separated from Family 4

Want to return to Hungary (Neutral) 4

Afraid of Infiltrated Secret Police 3

Conditions in Camps (Neutral) 3

Demonstrating 3

Fascist 3

Given Preference Over Other Refugee Groups 3

Men, Women, And Children 3

Number to Yugoslavia 3

Passenger 3

Poorly Dressed 3

Accepted to The Us (Temporarily) 2

Attempted Suicide 2

Tired 2

Exiled 2

Happy with Circumstances 2

Keeping Traditions 2

Pilgrims 2

Pitied 2

Sick 2

Single 2

Want to Stay in Australia 2

Want to Stay in Austria 2

Well-Dressed 2

Adopted 1

Asked to Show Loyalty 1

Average 1

Bachelors 1

Blackmailed by a Hungarian Diplomat 1

Can Go Back to Hungary 1

Crisis 1 
Criticized by the President of the

American Medical Association

Deprived of Life in Their Own Country 1

Destitute

Did Not Want to Go to the US

Died

Extra

Emotional

Eyewitness

Fake

Fearful

Feminine

Hapless

Homesick

Jittery

Married at St. Peters

Negative Physical Description (Lame)

Non-Assimilating

Originally from the US

Orphans

Patriots

Plan to Be Married

Popular

Protective

Returned to Hungary (Gave up

Hope of Getting out of Camps)

Sacrificed

Shares Traditions

Sports Fans

Strangers

Supported by Chancellor Julius Raab

Supported by University Funds

Want to Leave Yugoslavia

Want to Stay Near Hungary

Would Return to Hungary if the

Situation Changes

Frequency of UP Attributes

\begin{tabular}{ll}
\hline Attribute & Frequency \\
\hline Received Help and Supplies & 50 \\
Relational & 44 \\
Jobs & 35 \\
Youth & 34 \\
Supported by a Government Official & 21
\end{tabular}


Problem/Need 20

Adult/Men/Women 19

Struggle to get into Austria $\quad 19$

Ages $\quad 17$

Assimilating/Learned English $\quad 17$

Fled 15

Procedures/Processes 13

Welcomed 13

Arrived by Ship or Air to the US 11

Accepted to the US (General) 10

Found/Sought Freedom/Safety/Haven $\quad 10$

Number to Austria 10

Positive Emotion (Cheerful, Happy,

Hopeful, Joyful, Laughing, Optimistic) 10

Shot by Russians 10

Conditions in Hungary (negative) 9

Students 8

Accepted to Other Countries 8

Religious (Cardinal, Catholic,

Jewish, Lutheran, Protestant) 8

Want to go to the US 8

Criticized by Government Officials

(Burleson and Walter) 7

Freedom Fighters 7

Positive Description (Brave,

Courageous, Defiant, Loyal,

Symbol of Freedom, Worthy) 7

Sponsored 7

Helped by Americans 5

Participated in the Revolution 5

Thankful 5

Unhappy with Their Circumstances 5

5,000 Permitted to the US Under

the Refugee Relief Act 4

Accepted to the US (Parolees) 4

Accepted to the US (Visas) 4

Anti-Communist 4

Fear for Family Members Still in Hungary 4

Helped (General) 4

Number to Yugoslavia 4

Patriots 4

Sent Back to Hungary (Communist) 4

21,500 Authorized to Come to the US 3

Communist 3

Group 3

Has Goals/Aspirations 3 
Lacking Plans

Physical Description Neutral (Blond, Short, Plump, Stocky, Busy-Browed

Man)

Separated from Family 3

Supported by Religious Affiliations 3

Urged to Return Home by Hungary

Government

Victims

Visited by Nixon

Accepted to the US (Temporary) 2

American Citizen 2

Attempted Suicide 2

Chose Not to Return to Hungary 2

Conditions in Camps (Neutral) 2

Conditions in Camps (Positive) 2

Fearful of Russians 2

Helped by the Red Cross 2

Members of the Hungarian Army 2

Language Barrier 2

Little 2

Plighted 2

Reconnected with Family Members 2

Returned to Hungary (Neutral) 2

Want to go to Australia 2

Admired 1

Aliens 1

Celebrating 1

Comfortable 1

Compared to Immigrants ("Wetbacks") 1

Compared to Other Refugees 1

Conditions in Camps (Negative) 1

Crippled 1

Danced 1

Desperate 1

Determined to Become Good and

Useful Citizens 1

Died 1

Doesn't Know Anyone in the US 1

Engaged 1

Excited to be in America 1

Given Preference Over Other Refugee

Groups

Helped Other Refugees 1

Ill 1

Joking 1 
Lucky

Men, Women, and Children

Negative Description (Opportunist)

Peasant

Plan to Repay Their Transportation

Costs to Oregon

Positive Description (Skilled)

Rebels

Sponsored by a Religious Affiliation 1

Struggle to get to Yugoslavia

Supported by the Red Cross

Very Happy to be in America

Want to go to Canada

Want to Return to Hungary when the

Situation Changes

Sad Emotion (Weary)

Without a Country

Did Not Want to go to the US 
Appendix B

Frequency of AP Values

Value

Frequency

Economic impact of refugees - Transparency about funding refugees is important 90

Character of refugees - Refugees are good people

82

Support for refugees - Refugees need help

75

Support for refugees - Refugees are victim patriots

71

Economic impact of refugees - Funding refugees has positive consequence

59

Character of refugees - Refugees are bad people

Character of refugees - Refugees are just people

Support for refugees - Refugees are less important than national security

Responsibility for refugees - The United States needs to do its share to help

Responsibility for refugees - Everyone should be helping refugees

Economic impact of refugees - Funding refugees is bad for the economy

Responsibility for refugees- European countries should be helping refugees

\section{Frequency of UP Values}

Value Frequency

Support for refugees - Refugees are victim patriots

Support for refugees - Refugees need help

Economic impact of refugees - Transparency about funding refugees is important 27

Character of refugees - Refugees are good people

Economic impact of refugees - Funding refugees has positive consequences $\quad 21$

Economic impact of refugees - Funding refugees is bad for the economy 7

Support for refugees - Refugees are less important than national security 4

Character of refugees- Refugees are just people

Responsibility for refugees - The United States needs to do its share to help 4

Character of refugees - Refugees are bad people 3

Responsibility for refugees - Everyone should be helping refugees 2 
Appendix C

Frequency of US News and World Report Attributes

\begin{tabular}{|c|c|}
\hline Attributes & Frequency \\
\hline Jobs & 38 \\
\hline Ages & 26 \\
\hline Fled & 18 \\
\hline Relational & 18 \\
\hline Received Help and Supplies & 18 \\
\hline Escapees from Communism & 17 \\
\hline Number to Austria & 16 \\
\hline Students & 16 \\
\hline Accepted to the US (General) & 15 \\
\hline Proud, Defiant, Unbroken, Extraordinary & 14 \\
\hline Struggle to Reach Austria & 14 \\
\hline Participated in the Revolution & 10 \\
\hline Accepted by other countries & 9 \\
\hline Problem/Need & 9 \\
\hline Shot at by Russians/Hungarian police & 9 \\
\hline Supported by government officials (Eisenhower, & \\
\hline Nixon) & 9 \\
\hline Freedom fight, revolution, rebel & 8 \\
\hline Anti-communist & 7 \\
\hline Processes/Procedures & 7 \\
\hline Accepted to the US (parole) & 4 \\
\hline Sponsored & 4 \\
\hline Want to return to Hungary (neutral) & 4 \\
\hline Welcome & 4 \\
\hline Accepted to the US (visas) & 3 \\
\hline Criticized by Walter & 3 \\
\hline Friends & 3 \\
\hline Negative feeling (sad eyed, bewildered) & 3 \\
\hline $\begin{array}{l}\text { Positive description (best of Hungary, valued, } \\
\text { experienced) }\end{array}$ & 3 \\
\hline Airlifted or shipped to the US & 3 \\
\hline Victims of communism/oppression & 3 \\
\hline Accepted to the US (temporary) & 2 \\
\hline Communist/operative/spy/negative & 2 \\
\hline Would return to Hungary if there was a & \\
\hline change in government & 2 \\
\hline Men, women, and children & 2 \\
\hline Nationalist & 2 \\
\hline Patriots & 2 \\
\hline Physical feature & 2 \\
\hline
\end{tabular}


Plighted 2

Priority to go to the US 2

Want to go to the US 2

Could take jobs away from Americans 1

Encouraged by US to liberate Hungary 1

Fugitives 1

Homeless 1

Ill 1

Migrant 1

From bigger Hungarian cities 1

Negative experience in US 1

No occupation 1

Left Hungary purely for economic reasons $\quad 1$

Peaceful 1

Retired people 1

Sent back to Hungary (communist/lied) 1

Townspeople 1

Woman 1

Frequency of Time Attributes

\begin{tabular}{ll}
\hline Attributes & Frequency \\
\hline Jobs & 22 \\
Adults (men, women) & 18 \\
Received Help and Supplies & 15 \\
Struggle to get to Austria & 14 \\
Youth & 13 \\
Negative emotion (unhappy, bewildered, & 13 \\
nervous, embittered, scarred) & \\
Relational & 10 \\
Employable (skilled, trained, professional, & 8 \\
educated) & \\
Brave & 8 \\
Number to Austria & 7 \\
Freedom fighter & 6 \\
Accepted by other countries & 6 \\
Supported by government officials (Nixon, & \\
Eisenhower) & 6 \\
Procedures/processes & 6 \\
Sought freedom/new life & 5 \\
Greeted/welcomed & 5 \\
Fled/escaped & 5 \\
Negative conditions in Hungary (prisoner, & \\
unionized) & 5 \\
Need/problem & 5
\end{tabular}


Accepted by the US (parole) 5

21,500 to be admitted to the US 5

Shipped or airlifted to US 4

Returned to Hungary (neutral) 3

Negative physical description (thin, aging) 3

Anti-communist 3

Age 3

Oppressed 2

Grateful 2

Fugitives 2

Compared to "negroes" 2

Arrived at Camp Kilmer 2

Accepted by the US (general) 2

Able-bodied 2

Religious (Jews, clergymen) 2

Student 1

Pregnant 1

Plighted 1

Old 1

Men, women, and children 1

Immigrants 1

Compared to other refugee groups 1

Communist 1

Number entering Yugoslavia 1

Frequency of Newsweek Attributes

\begin{tabular}{ll}
\hline Attributes & Frequency \\
\hline Jobs & 32 \\
Received Help and Supplies & 29 \\
Youth & 23 \\
Relational & 21 \\
Students & 12 \\
Age & 11 \\
Fleeing & 11 \\
Participated in the Revolution & 10 \\
Struggle to get to Austria & 8 \\
Supported by Americans & 8 \\
Assimilating/learning English & 8 \\
Adults (men, women) & 8 \\
Supported by government officials (Nixon, & 8 \\
Eisenhower) & 7 \\
Escapees & 7
\end{tabular}


Freedom fighters/rebels/revolutionaries $\quad 6$

Skilled/trained/well-educated 6

Number to Austria 5

Accepted by other countries 5

Looking forward to their new home/new life 5

Negative feeling/emotion (uncertain, under duress,

crying)

Physical appearance (neutral) 5

Seeking freedom 5

Thankful/grateful 5

Frail, ill, crippled 4

Individual descriptions 4

Procedure/process 4

Returned to Hungary (neutral) 4

Welcome 4

21,500 allowed in the US 3

Accepted to the US (general) 3

Anti-communist 3

Emotional (positive) 3

Looking for a job 3

Sent back to Hungary (communist/false statements) 3

Airlifted or shipped to the US 2

Group 2

Lovers 2

Negative experience in US 2

Physical appearance (positive) 2

Pilgrims 2

Positive description (remarkable, brave, well-liked) 2

Shot or injured by the Russians/Hungarians 2

Would like to return to Hungary if the situation

changes

A statistic

Communists

Criticized

Elderly

Fearing for those still in Hungary 1

Given asylum 1

Homeless 1

Immigrants 1

Men, women, and children 1

Most are from cities 1

Need/problem 1

Ordinary people 1

Plighted 1

Returned to Hungary (resettlement-negative) 1

Returnees will probably be used as a propaganda 
display but the Kadar regime

Sponsored

Sponsored by a church 
Appendix D

Frequency of US News and World Report Values

Value

Frequency

Economic impact of refugees - Transparency about funding refugees is important 7

Economic impact of refugees - Funding refugees has positive consequences 6

Character of refugees - Refugees are good people 5

Responsibility for refugees - The United States needs to do its share to help 5

Support for refugees - Refugees are victim patriots 4

Support for refugees - Refugees need help $\quad 4$

Responsibility for refugees - Everyone should be helping refugees 3

Support for refugees - Refugees are less important than national security 2

Economic impact of refugees - Funding refugees is bad for the economy 1

Responsibility for refugees- European countries should be helping refugees

Frequency of Time Values

Value

Frequency

Support for refugees - Refugees need help 27

Economic impact of refugees - Funding refugees has positive consequences $\quad 14$

Support for refugees - Refugees are victim patriots 9

Character of refugees - Refugees are good people 9

Responsibility for refugees- The United States needs to do its share to help 5

Support for refugees - Refugees are less important than national security 4

Economic impact of refugees - Transparency about funding refugees is important 4

Character of refugees- Refugees are just people 4

Economic impact of refugees - Funding refugees is bad for the economy 2

Responsibility for refugees- Everyone should be helping refugees

Frequency of Newsweek Values

Value

Frequency

$\begin{array}{ll}\text { Support for refugees - Refugees need help } & 22\end{array}$

Economic impact of refugees - Funding refugees has positive consequences $\quad 17$

$\begin{array}{ll}\text { Support for refugees - Refugees are victim patriots } & 10\end{array}$

Character of refugees - Refugees are good people $\quad 7$

Economic impact of refugees - Transparency about funding refugees is important 6

Character of refugees- Refugees are just people 5

Responsibility for refugees - The United States needs to do its share to help 4

Economic impact of refugees - Funding refugees is bad for the economy 2

Support for refugees - Refugees are less important than national security 1

Responsibility for refugees - Everyone should be helping refugees 1

Responsibility for refugees - European countries should be helping refugees 1 
Appendix E

Frequency of New York Time Attributes

\begin{tabular}{|c|c|}
\hline Attribute & Frequency \\
\hline Received help and supplies & 161 \\
\hline Youth & 100 \\
\hline Jobs (total) & 96 \\
\hline Number to Austria & 68 \\
\hline Accepted by other countries & 64 \\
\hline Problem/need & 54 \\
\hline Assimilating/learning English & 53 \\
\hline Relational & 51 \\
\hline Ages & 50 \\
\hline Fled & 44 \\
\hline Struggle to get into Austria & 43 \\
\hline Procedure/processes & 42 \\
\hline Accepted by the US (general) & 34 \\
\hline Welcomed/greeted & 31 \\
\hline Participated in the revolution & 30 \\
\hline Conditions in Hungary (negative) & 29 \\
\hline Unhappy with circumstances & 27 \\
\hline Found/searched for freedom/haven/safety & 26 \\
\hline Adults & 26 \\
\hline Victim (imprisoned, tortured, oppressed, persecuted) & 24 \\
\hline Escapees & 22 \\
\hline Flown to the US & 18 \\
\hline Freedom fighter & 18 \\
\hline $\begin{array}{l}\text { Positive description (Finest people in Hungary, } \\
\text { not the huddled masses, best, generally favorable, } \\
\text { magnificent, eager to learn, independent, valuable, } \\
\text { vigorous, outstanding, talented, ambitious) }\end{array}$ & 18 \\
\hline Number in Yugoslavia & 16 \\
\hline Reconnected with relatives & 15 \\
\hline Supported by the Red Cross & 15 \\
\hline Want to come to the US & 15 \\
\hline Accepted by the US (parolee) & 14 \\
\hline Group & 14 \\
\hline Anti-communist & 13 \\
\hline Student & 11 \\
\hline Trained/skilled/qualified/professional/educated & 11 \\
\hline Religious (cardinal, clergymen, Jewish) & 11 \\
\hline Conditions in camps (negative) & 10 \\
\hline Supported by government figures & 10 \\
\hline Shot at by Russians/Hungarian police & 10 \\
\hline Brave/daring/courageous/self-sacrificing/strong & 10 \\
\hline
\end{tabular}


Fear for family members still in Hungary 9

Grateful 8

Negative description (no-goods, communist agents, communists, anti-Semitic) 9

Sent back to Hungary negative (communist, criminal) 8

Proud/Spirited 8

Condition in camps (positive) 7

Newcomers $\quad 7$

Plighted $\quad 7$

Returned to Hungary (neutral) 7

Accepted by the US (visa) 6

Accepted by the US (temporarily) 6

Arrived by ship to the US 6

Compared to other refugee groups 6

Men, women, and children 6

Physical description (neutral) 6

Emotion negative (crying, exhausted, astonished, weary) 5

Exile 5

Fugitives $\quad 5$

Helped the US economy 5

Patriot 5

Want to return home when the situation changes 5

Hungarian Army members 5=

Criticized by Walter 4

Decided not to return home 4

Displaced persons/dispossessed 4

Emotion positive (joyful, hopeful, not bitter) 4

Homeless 4

Immigrant 4

Language barrier $\quad 4$

Negative actions (arraigned for possessing an unregistered still, fought with Austrian communists, stabbed a welfare worker, took over a flight so they

could go to the west)

Sponsored

Unwelcome 4

Given preference over others in need 3

Non-assimilated 3

Positive emotion (happy, joyous) 3

Want to work/must work/hard worker 3

Civilian 2

Compared to Jewish refugees 2

Continued family traditions $\quad 2$

Ill (emotionally disturbed, frail) 2

Pilgrims 2

Ex-communist 2 
Rebels/revolutionaries $\quad 2$

Sponsored by religious sources 2

Unarmed 2

Want to leave Austria 2

Are increasingly warned against any kind of political activity in Austria 1

Aristocrats 1

Born in refugee camp 1

Bride 1

Burden 1

Colleague 1

Committed suicide 1

Compared to Mexicans 1

Condition in the camps (neutral) 1

Criticized by Mike Monroney (can't all be moved

to America) 1

Disowned in Hungary 1

Drably dressed 1

Eager to tell their stories 1

Elderly 1

Expect help 1

Fortunate 1

Given preference over Russian athletes 1

Helped by religious sources 1

Holds a union card in his native country 1

Hungry 1

Magyar

Migrants 1

Mostly from Budapest 1

No orphans 1

Opportunist 1

Ordinary 1

Orphans 1

Peasants 1

Physical description (positive) in good health 1

Pregnant 1

Satellite people 1

Should stay in Austria 1

Supported by the British 1

Unfortunate 1

Wanted to stay in Europe 1

Wants to return to Hungary 1

Welcome to return to Hungary (per Budapest Radio) 1

Well-advanced 1

Well-dressed 1

Witnesses 1 
Appendix F

Frequency of New York Time Values

Value

Frequency

Economic impact of refugees - Transparency about funding refugees is important 103

Support for refugees - Refugees need help

Economic impact of refugees- Funding refugees has positive consequences

Character of refugees - Refugees are good people

Support for refugees - Refugees are victim patriots

Responsibility for refugees - The United States needs to do its share to help

Character of refugees - Refugees are bad people

Support for refugees - Refugees are less important than national security

Economic impact of refugees - Funding refugees is bad for the economy

Responsibility for refugees - Everyone should be helping refugees 


\section{CURRICULUM VITA}

Cecelia Hunt

1142 S. $6^{\text {th }}$ Street, Apt. 1, Louisville, KY 40203

502.551.0551, cecelia.hunt@louisville.edu

\section{EDUCATION}

Master of Arts in Communication

University of Louisville, Louisville, KY

Bachelor of Arts in Communication Studies

Indiana University Southeast, New Albany, IN
Expected Graduation: May 2017

Degree Conferred: May 2012

\section{TEACHING EXPERIENCE}

University of Louisville

- Instructor, COMM 111: Intro to Public Speaking, two sections. Spring 2017.

- Instructor, COMM 111: Intro to Public Speaking, two sections. Fall 2016.

- Guest Lecturer, COMM 305: Mass Communication. Lectured on media law. Spring 2016.

- Guest Lecturer, COMM 320: Newswriting. Lectured on media law. Spring 2016.

- Participant, Graduate Teaching Academy. Year-long series designed to teach knowledge, skills, and excellence in college teaching. 2015-2016.

- Guest Lecturer, COMM 463: Food, Fashion, \& Fun. Lectured on media law. Fall 2015.

- Graduate Teaching Assistant, COMM 305: Mass Media. Created lecture notes and led review sessions. Fall 2015.

\section{RESEARCH EXPERIENCE}

Principal Investigator, University of Louisville, Fall 2016 
"The Road to Advertising Freedom: A Comparative Analysis of Outdoor Advertising in Hungary and Cuba," analysis of Hungarian and Cuban billboards in conjunction with each country's past and current political climates

Co-Investigator, University of Louisville, 2015-2016

“"Native' Advertising: An Evaluation of Nike's N7 Social Media Campaign," researching Fortune 500 company social media campaign.

Research Assistant, Indiana University Southeast, 2011

Assisted Communication Department faculty member Dr. Audrey Deterding

Research Assistant, Indiana University Southeast, 2009

Assisted members of Sociology Department

\section{CONFERENCE PRESENTATIONS}

Panel Presenter

“"Native' Advertising: An Evaluation of Nike's N7 Social Media Campaign."

National Communication Association Conference, Philadelphia, Pennsylvania, November, 2016.

Panel Presenter

"The Road to Advertising Freedom: A Comparative Analysis of Outdoor Advertising in Hungary and Cuba." Kentucky Communication Association Conference, Bowling Green, Kentucky, September 2016.

Session Presenter

"Nike Markets Merchandise to Native Americans." Paper presented at American Indian Studies Association Conference, Tempe, Arizona, February 2016.

\section{PROFESSIONAL EXPERIENCE}

University of Louisville, 2015-2016

Graduate Teaching Assistant, responsible for innovative research on marketing campaign. Edit/review professor's work for publication. Assist coordinating undergraduate Service Learning Trip to a northern Wisconsin reservation. Evaluate student papers and record grades for five classes. Help write exams and quizzes. Work with Blackboard program. Consult with professor on course policies. Proctor exams. Review syllabi. Produce flyers for department and classes, such as for the Native American Film Festival. File research journals. Assist Director of Women Who Write, a Louisville writing group.

University of Louisville, 2015

Native American Film Festival Public Relations Coordinator, led social media campaign resulting in record-breaking attendance. Fall 2015. 
The Learning House, 2014-2015

Academic Advisor and Team Supervisor

21c Museum Hotels, 2012-2014

Front Office Supervisor

\section{GRANTS AND AWARDS}

Outstanding Graduate Student, Spring 2017.

University of Louisville Department of Communication.

National Communication Association Top Paper in American Studies Division, 2016. Awarded for co-authored paper, "Native' Advertising: An Evaluation of Nike's N7 Social Media Campaign" for annual conference in Philadelphia in November 2016.

Graduate Teaching Assistantship Academy Professional Development Award, Fall 2016. Award to support GRE registration fee.

Graduate Student Council Travel Grant, University of Louisville, Fall 2016. Awarded to support travel to the National Communication Association Conference in Philadelphia.

Graduate Network in Arts and Sciences Travel Grant, University of Louisville, Spring 2016.

Awarded to support travel to American Indian Studies Conference in Tempe, Arizona.

Graduate Student Council Travel Grant, University of Louisville, Spring 2016. Awarded to support travel to American Indian Studies Conference in Tempe, Arizona.

Communication Department Travel Funding, University of Louisville, Spring 2016. Awarded to support travel to American Indian Studies Conference in Tempe, Arizona.

Graduate Teaching Assistantship, University of Louisville, 2015-2017.

Two-year tuition remission and stipend for graduate studies in communication.

\section{PUBLICATIONS}

Hunt, C., Crenshaw, C., \& D'Silva, M. (2017). The road to change through the lens of advertising: A comparative analysis of outdoor media in Hungary, Cuba, and the U.S. Kentucky Journal of Communication. 
Sanders, W., Phillips, S., \& Hunt, C. (in submission). "Native" Advertising: An Evaluation of Nike's N7 Social Media Campaign. American Indian Culture and Research Journal.

Hunt, C., \& Goodman S. (2010). Enrichment Through the Arts: The Arts Institute at IU Southeast. The Voice, 3, 17-18.

\section{AFFILIATIONS}

National Communication Association, 2016

Kentucky Communication Association, 2016

American Indian Studies Association, 2016

Native American Studies Association, University of Louisville, 2015

German Club, Indiana University Southeast, 2011-2012

Founding President

\section{TRAINING AND CERTIFICATIONS}

\section{CITI Training}

Certified in Human Subjects and HIPAA-Research (Social, Behavioral, or Educational Research)

\section{QDA Miner}

Trained in using software program for analyzing text and images.

\section{SERVICE WORK}

Women Who Write 2016

Transformation Tea 2016

Graduate Network in Arts and Sciences 2016-2017

Arts \& Sciences Planning and Budgeting Committee, 2016 